\title{
Metabolic Reprogramming in Cancer: Role of HPV 16 Variants
}

\author{
Adán Arizmendi-Izazaga ${ }^{1}\left(\mathbb{D}\right.$, Napoleón Navarro-Tito ${ }^{2}{ }^{\circledR}$, Hilda Jiménez-Wences ${ }^{3,4}{ }^{\circledR}$, \\ Miguel A. Mendoza-Catalán 1,3(1), Dinorah N. Martínez-Carrillo ${ }^{3,4} \mathbb{C}^{\mathbb{D}}$, Ana E. Zacapala-Gómez ${ }^{1}$, \\ Monserrat Olea-Flores ${ }^{2}$, Roberto Dircio-Maldonado ${ }^{4,5}{ }^{\circledR}$, Francisco I. Torres-Rojas ${ }^{1}{ }^{\mathbb{D}}$, Diana G. Soto-Flores ${ }^{1}$, \\ Berenice Illades-Aguiar ${ }^{1,5}$ and Julio Ortiz-Ortiz ${ }^{1,3, * \mathbb{B}}$
}

1 Laboratorio de Biomedicina Molecular, Facultad de Ciencias Químico Biológicas, Universidad Autónoma de Guerrero, Av. Lázaro Cárdenas S/N, Ciudad Universitaria, Colonia La Haciendita, Chilpancingo C.P. 39090, Guerrero, Mexico; adanarizmendi@uagro.mx (A.A.-I.); mamendoza@uagro.mx (M.A.M.-C.); zak_ana@yahoo.com.mx (A.E.Z.-G.); trisrael5@yahoo.com.mx (F.I.T.-R.); diana.sotof@hotmail.com (D.G.S.-F.); b.illadesaguiar@gmail.com (B.I.-A.)

2 Laboratorio de Biología Celular del Cáncer, Facultad de Ciencias Químico Biológicas, Universidad Autónoma de Guerrero, Av. Lázaro Cárdenas S/N, Ciudad Universitaria, Colonia La Haciendita, Chilpancingo C.P. 39090, Guerrero, Mexico; nnavarro@uagro.mx (N.N.-T.); monseolea@uagro.mx (M.O.-F.)

3 Laboratorio de Investigación en Biomoléculas, Facultad de Ciencias Químico Biológicas, Universidad Autónoma de Guerrero, Av. Lázaro Cárdenas S/N, Ciudad Universitaria, Colonia La Haciendita, Chilpancingo C.P. 39090, Guerrero, Mexico; wences2009@hotmail.com (H.J.-W.); dinomtzcar@outlook.com (D.N.M.-C.)

check for updates

Citation: Arizmendi-Izazaga, A.;

Navarro-Tito, N.; Jiménez-Wences, H.; Mendoza-Catalán, M.A.; Martínez-Carrillo, D.N.; Zacapala-Gómez, A.E.; Olea-Flores, M.; Dircio-Maldonado, R.; Torres-Rojas, F.I.; Soto-Flores, D.G.; et al. Metabolic Reprogramming in Cancer: Role of HPV 16 Variants. Pathogens 2021, 10, 347. https:// doi.org/10.3390/pathogens10030347

Academic Editor: Anna Rosa Garbuglia

Received: 18 February 2021

Accepted: 14 March 2021

Published: 16 March 2021

Publisher's Note: MDPI stays neutral with regard to jurisdictional claims in published maps and institutional affiliations.

Copyright: (c) 2021 by the authors. Licensee MDPI, Basel, Switzerland. This article is an open access article distributed under the terms and conditions of the Creative Commons Attribution (CC BY) license (https:/ / creativecommons.org/licenses/by/ $4.0 /)$.
4 Laboratorio de Investigación Clínica, Facultad de Ciencias, Químico Biológicas, Universidad Autónoma de Guerrero, Av. Lázaro Cárdenas S/N, Ciudad Universitaria, Colonia La Haciendita, Chilpancingo C.P. 39090, Guerrero, Mexico; dircio.mr@gmail.com

5 Laboratorio de Diagnóstico e Investigación en Salud, Facultad de Ciencias Químico Biológicas, Universidad Autónoma de Guerrero, Av. Lázaro Cárdenas S/N, Ciudad Universitaria, Colonia La Haciendita, Chilpancingo C.P. 39090, Guerrero, Mexico

* Correspondence: julioortiz@uagro.mx; Tel.: +52-747-471-0901

\begin{abstract}
Metabolic reprogramming is considered one of the hallmarks in cancer and is characterized by increased glycolysis and lactate production, even in the presence of oxygen, which leads the cancer cells to a process called "aerobic glycolysis" or "Warburg effect". The E6 and E7 oncoproteins of human papillomavirus 16 (HPV 16) favor the Warburg effect through their interaction with a molecule that regulates cellular metabolism, such as p53, retinoblastoma protein (pRb), c-Myc, and hypoxia inducible factor $1 \alpha(\mathrm{HIF}-1 \alpha)$. Besides, the impact of the E6 and E7 variants of HPV 16 on metabolic reprogramming through proteins such as HIF- $1 \alpha$ may be related to their oncogenicity by favoring cellular metabolism modifications to satisfy the energy demands necessary for viral persistence and cancer development. This review will discuss the role of HPV 16 E6 and E7 variants in metabolic reprogramming and their contribution to developing and preserving the malignant phenotype of cancers associated with HPV 16 infection.
\end{abstract}

Keywords: HPV 16 variants; metabolic reprogramming; cancer

\section{Introduction}

Cancer is a neoplasm that involves the alteration of at least six biological capacities: resisting cell death, sustaining proliferative signaling, evading growth suppressors, activating invasion and metastasis, enabling replicative immortality, inducing angiogenesis, and two emerging hallmarks - evading immune destruction and reprogramming energy metabolism, related to tumor initiation and progression [1]. In cancer, metabolic reprogramming promotes the energy increase necessary for growth, cell division, migration, and metastasis [2,3]. Otto Warburg was the first to propose that, unlike normal adult tissues, cancer cells produce energy mainly through aerobic glycolysis rather than oxidative phosphorylation, a state known as "aerobic glycolysis" or Warburg effect [2,4]. The Warburg 
effect favors obtaining adenosine $5^{\prime}$-triphosphate (ATP) necessary for cancer proliferation and metastasis by aerobic glycolysis $[5,6]$.

Approximately $16 \%$ of cancer cases worldwide are caused by an infectious agent, mainly due to infection by oncogenic viruses [7] and about $5 \%$ are caused by high-risk human papillomavirus (HR-HPV) [8]. HR-HPV 16 is the leading cause of more than half of cervical cancer cases globally [9] and has been found in $50-55 \%$ of invasive cervical cancer cases [10]. It has also been linked to cancers such as head and neck, vulva, vagina, penis, and anal [11]. Currently, several reports show that human papillomavirus (HPV) 16 variants alter the expression of various genes related to apoptosis, adhesion, metastasis, angiogenesis, and metabolism [12]. These variants interact with multiple cellular proteins such as p53, retinoblastoma protein (pRb), p300/CBP, and pyruvate kinase 2 (PKM2), promoting gain or loss of their functions [13]. These have also been associated with a more significant oncogenic potential of these variants and the severity of precancerous lesions [14,15]. Additionally, it has been observed that E6 variants increase the expression of genes related to metabolic processes [16] and regulate signaling pathways related to glucose metabolism [17]. This review addresses the oncogenic role of HPV 16 variants in metabolic reprogramming modulation as a possible mechanism involved in carcinogenesis.

\section{Energy Metabolism}

Cellular energy metabolism is the bioprocess responsible for converting nutrients such as carbohydrates, lipids, and proteins into energy and biomass to maintain cell survival and proliferation [5]. Glucose is the main energy source for mammalian cells [5]. The entry of glucose to the cell is through solute transporters (SLC): $\mathrm{Na}^{+} /$Glucose cotransporters (SGLTs) and glucose transporters (GLUTs) [18]. Once glucose is internalized through the cell membrane by GLUTs or SGLTs, glycolysis begins, which represents one of the main ATP synthesis pathways. Physiologically, glycolysis occurs in the absence or presence of oxygen $\left(\mathrm{O}_{2}\right)$ [19]. Enzymes involved in glycolysis are hexokinase (HK), glucose-6-phosphate isomerase (PGI), phosphofructokinase (PFK), aldolase (ALDO), triose phosphate isomerase (TPI), glyceraldehyde-3-phosphate dehydrogenase (GAPDH), phosphoglycerate kinase (PGK), phosphoglycerate mutase (PGM), enolase (ENO), and pyruvate kinase (PK) [19]. The final product of glycolysis under normal oxygen conditions is pyruvate, which is converted into acetyl-coenzyme A (acetyl-CoA) by the enzymatic complex pyruvate dehydrogenase (PDH), to be oxidized to $\mathrm{CO}_{2}$ and $\mathrm{H}_{2} \mathrm{O}$ through the cycle of tricarboxylic acids (TCA) and the electron transport chain (ETC) [20]. However, in hypoxia, pyruvate is converted to lactate by the enzyme lactate dehydrogenase A (LDHA) [21].

On the other hand, lipids also produce acetyl-CoA from the $\beta$-oxidation of fatty acids obtained from lipolysis or the diet [22]. Furthermore, many of the carbon skeletons of non-essential amino acids are intermediates of glycolysis and the TCA cycle used as energy sources [23]. The entry of acetyl-CoA to the TCA cycle is connected to cellular respiration, which integrates different energy sources derived from the diet, such as glucose, glutamine, and fatty acids [24]. The TCA cycle produces metabolic intermediates that are used as precursors for the synthesis of macromolecules, such as citrate in the synthesis of fatty acids and $\alpha$-ketoglutarate, succinyl-CoA, and fumarate in the synthesis of amino acids; malate in gluconeogenesis; and electron acceptors that are used in processes such as the electron transport chain (ETC) [24]. Biochemical reactions in energy metabolism are regulated by various mechanisms involving the availability of substrates and allosteric regulation, which allows the cell to control energy production according to its energy state through the $\mathrm{NADH} / \mathrm{NAD}+$ ratio, ATP, and nutrients availability [24,25]. However, since 1930 it has been described that the normal conditions of energy metabolism are affected in cancer by metabolic reprogramming [26].

\section{Metabolic Reprogramming in Cancer}

Metabolic reprogramming is one of the critical hallmarks in cancer progression [27]. It is characterized by an increase in glycolysis to satisfy energy demand, anabolic, biosyn- 
thetic, and growth requirements, which promote the hyper-proliferation of cancer cells [28]. The absence of nutrients and $\mathrm{O}_{2}$ and secretion of secondary metabolites and carbon dioxide promote the formation of new blood vessels associated with the tumor, mainly activated by growth factors and tumor progression [29]. The best-known angiogenic regulators in cancer are vascular endothelial growth factor A (VEGF-A), von Willebrand factor (VWF), and thrombospondin-1 (TSP-1) [27,30]. In cancer models, it has been observed that angiogenesis is active from the early stages of tumor development to terminal stages. Besides, the regulation of angiogenesis and the supply of nutrients to satisfy energy demands and the excretion of metabolites are a limiting steps in developing tumors [29].

Since 1930 it was observed that, unlike normal cells, cancer cells show increased glycolysis even in the presence of $\mathrm{O}_{2}$; this process has been called "aerobic glycolysis" or "Warburg effect" [27]. Currently, it is known that the decrease in the incorporation of pyruvate in the mitochondria is the product of the high supply of glucose, glycolysis and of processes such as glutaminolysis, which is necessary for the synthesis of amino acids $[3,28]$. Furthermore, it has been observed that this metabolic reprogramming increases the expression of glucose transporters, especially GLUT1 and GLUT3, substantially increasing the importation of glucose into the cytoplasm of the cell [31-33]. Increased glycolysis in cancer cells is associated with the activation of oncogenes such as RAS and MYC or the silencing of tumor suppressor genes such as TP53 [3,32,34,35]. Similarly, an increase in the expression of glycolytic enzymes related to the Warburg effect such as HK2, PFK2, ALDO, GAPDH, PGK1, ENO1, PKM2, and LDHA has been observed in different cancers. In liver cancer cell lines such as Hep3B, HepG2, JHH5, JHH7, and Huh7, the expression of HK2 has been observed, while in other cancers such as lung, breast, colon, and also in HLF and HH6, liver cancer cell lines are expressed as both HK2 and HK1 [36]. The enzyme 6-phosphofructo-2-kinase/fructose-2,6-bisphosphatase (PFKFB or PFK-2) has been reported to be overexpressed in most tumor cells under hypoxic conditions [37], where it is responsible for maintaining cellular levels of fructose-2,6-bisphosphate (F-2,6-BP) by synthesizing or degrading fructose-2,6-bisphosphate. The kinase domain synthesizes F-2,6BP from F-6-P and ATP. Simultaneously, the phosphatase site degrades F-2,6-BP to F-6-P and inorganic phosphate $(\mathrm{Pi})$, such that the $\mathrm{F}-2,6-\mathrm{BP}$ metabolite is regarded as the most potent allosteric activator of PFK-1 and an inhibitor of fructose-1,2-bisphosphatase [38]. ALDOA overexpression has also been found to be related to the Warburg effect in oral squamous cell carcinoma, osteosarcoma, hepatocellular cell carcinoma, and lung cancer. The overexpression of ALDOB plays an important role during the epithelial-mesenchymal transition. Likewise, the overexpression of ALDOC has been correlated with neuronal damage, such as schizophrenia, Alzheimer's disease, and traumatic brain injury [39]. Furthermore, ALDOA has been proposed as a potential biomarker and molecular target for the early detection of hepatocellular carcinoma [40]. GAPDH also plays a key role in maintaining the Warburg effect in various cancers, such as lung, prostate, and pancreatic adenocarcinoma [41-43]. Increased GAPDH expression is also characteristic of cervical carcinoma tissue cells. However, it is not yet related to conventional clinicopathological parameters, such as clinical stage, histological type, or differentiation degree [44]. Until now, GAPDH was considered a target in the metabolism of glucose in liver cancer via the coactivator-associated arginine methyltransferase 1 (CARM1), which methylates GAPDH at arginine 234 (R234), inhibiting its catalytic activity and decreasing the proliferation of tumor cells in vitro and in vivo [45]. In aerobic glycolysis, another of the glycolytic enzymes that are altered in cancer cells to promote and maintain the Warburg effect is the PGK1 enzyme, which has been observed to be overexpressed in breast, colon, and gastric cancer [46-48]. Furthermore, different variants of PGK1 that differ in structure and function and are related to differentiation in catalytic efficiency or thermodynamic stability and changes in their tertiary structure have been identified in tumors. It is currently known that PGK1 is regulated by the transcription factor HIF-1, which promotes its overexpression and increases glycolysis [49,50]. Enolase, specifically isoform 1 (ENO1), has been reported as a critical regulator in tumor formation since the silencing of ENO1 has implications in 
the adaptation of autophagy and catabolic pathways, which affects the growth of tumors, inducing senescence [51]. PKM2 has also been reported to be overexpressed in cancer cells. However, it has been observed that it is not the only isoform of PKM overexpressed in cancer [52]. Similarly, the regulation of PKM2 in cancer is important for controlling cell metabolism and tumor growth [53]. PKM2 expression has been reported to increase due to alternative splicing, controlled by members of the heterogeneous nuclear ribonucleoprotein (hnRNP) family: hnRNPA1, hnRNPA2, and polypyrimidine tract binding protein (PTB; also known as hnRNPI). The transcription factor and oncoprotein c-Myc has also been observed to regulate increased expression of the three hnRNPs, thus contributing to PKM2 expression in some cancers [52]. PKM2 has been proposed to fluctuate between an active tetramer and a less active dimer. The PKM2 tetramer has a high affinity for phosphoenolpyruvate (PEP) and favors pyruvate and ATP production. In cancer cells, active PKM2 is present if glucose is used for energy production or the synthesis of anabolic precursors such as amino acids, nucleic acids, and phospholipids [52]. LDHA, an isoform of LDH, is predominantly expressed in cancer cells as a transcriptional regulation product and is activated by post-translational modifications such as phosphorylation and acetylation to increase lactate production during tumor progression and metastasis in cancer [54]. In metabolic reprogramming, tumor cells can metabolize lactate as an energy source that can be transported to neighboring cancer cells, adjacent stroma, and vascular endothelial cells. Lactate also plays a key role in promoting tumor inflammation and angiogenesis [55].

It is currently known that $\mathrm{O}_{2}$ concentrations are significantly reduced in many human cancers compared to normal tissue [56]. Median $\mathrm{pO}_{2}$ in breast cancer is $\sim 10 \mathrm{~mm} \mathrm{Hg}$ compared to $\sim 65 \mathrm{~mm} \mathrm{Hg}$ in normal breast tissue [56]; $\mathrm{pO}_{2}$ in tumor tissue is $0-20 \mathrm{~mm} \mathrm{Hg}$ compared to normal tissue where it is $40 \mathrm{~mm} \mathrm{Hg}$ [57]. The decrease in $\mathrm{pO}_{2}$ in cancer is associated with an increased risk of tumor invasion and metastasis [58]. The low availability of $\mathrm{O}_{2}$ in solid tumors is observed at a distance of approximately $100 \mu \mathrm{m}$ from the blood vessels [59] due to hypoxic stress, favoring the activation of HIF1. Active HIF1 regulates the transcription of many genes such as TF (transferrin), HK2 (hexokinase 2), JMD1A (Jumonji domain-containing), CDH (cadherin), GLUT1, ALDO-C, LDH-A, PKM2, anhydrase carbonic IX (CAIX), ENO3,2, and PFKFB4 [60-62] that code for cancer-related proteins such as angiogenesis [63], genetic instability [64], invasion and metastasis [65,66], proliferation, glucose metabolism, and $\mathrm{pH}$ regulation [67-69]. HIF1 is composed of two subunits, the alpha and beta subunits (HIF-1 $\alpha$ and HIF-1 $\beta$ ) [70]; both subunits form the active dimer, necessary for the transcription of their target genes. The active HIF1 complex binds to DNA at specific sites called hypoxia response elements (HRE) in an RCGTG sequence. HIF- $1 \beta$ is constitutively expressed, while HIF- $1 \alpha$ has a half-life of $5-8 \mathrm{~min}$, which is increased under hypoxic conditions [71-73]. Under normal $\mathrm{O}_{2}$ conditions, HIF$1 \alpha$ is continuously expressed, but it is hydroxylated at two proline residues (P402 and P564) and one of asparagine (N803) by two dioxygenases, prolyl-4-hydroxylases (PHD) and asparaginyl hydroxylase or factor inhibitor HIF-1 $\alpha$ (FIH-1), respectively [74]. These dioxygenases require $\mathrm{O}_{2}$, ferrous ion $\left(\mathrm{Fe}^{2+}\right)$, and $\alpha$-ketoglutarate $(\alpha-\mathrm{KG})$ for their activity and generate carbon dioxide and succinate as products [69]. Hydroxylated HIF-1 $\alpha$ is ubiquitinated by the complex formed by von Hippel Lindau (VHL), Elongin C, Elongin B, Cullin 2 (CUL2), ring box protein 1 (RBX1), a ubiquitin E2 (E2) conjugating enzyme, and the spermidine/spermine protein N (1) -acetyltransferase 2 (SSAT2), to be subsequently degraded via the $26 \mathrm{~S}$ proteasome [74]. Hydroxylation of the asparagine residue located in C-TAD inhibits the binding of HIF- $1 \alpha$ to the transcriptional regulators CBP/p300; therefore, the transcriptional activity of HIF- $1 \alpha$ is inhibited $[75,76]$. Under hypoxic conditions, the activity of PHDs and FIH1 on HIF- $1 \alpha$ is affected, and metabolic reprogramming in a cancer cell is preferred [75]. The activity of PHDs and FIH1 also decreases in the absence of Fe ${ }^{2+}$ and $\alpha-K G$. On the other hand, the loss of the function of succinate dehydrogenase (SDH) and fumarate hydratase (FH) favor the accumulation of succinate and fumarate, which bind to PHDs by inhibiting their activity; the binding of $\mathrm{NAD}(\mathrm{P}) \mathrm{H}$ : quinone oxidoreductase 1 (NQO1) to the ODDD of HIF-1 $\alpha$ also inhibits the hydroxylation of HIF-1 $\alpha$. Likewise, the 
binding of the HSP90 chaperone in the domain Per-Arnt-SimA (PAS-A) of HIF-1 $\alpha$ protects it from a degradation pathway independent of PHD/VHL, mediated by the activated receptor kinase C (RACK1) [75,77]. Stabilized HIF-1 $\alpha$ is associated with polymerized microtubules and translocates to the nucleus when the motor protein dynein recognizes its nuclear localization signal (NLS). HIF-1 $\alpha$ forms the active HIF1 complex in the nucleus to regulate the transcription of its target genes [61,62,77] by binding to DNA in HREs [72]. Active HIF1 promotes the expression of glucose transporters such as GLUT1 that increases the amount of glucose in the cytoplasm [32,33], oncogenes such as c-Myc, and glycolytic enzymes related to the Warburg effect such as HK2, PFKFB or PFK-2, ALDOA- B, GAPDH, PGK1, ENO1, PKM2, and LDHA-B. These HIF-1a target enzymes have also been observed in different types of cancer associated with high-risk human papillomavirus (HR-HPV), including HPV 16 [36,52,53,78-81].

\section{Human Papillomavirus 16}

The HR-HPV that causes more than half of cervical cancer cases in the world is HPV 16 [9]; it has been found in 50-55\% of invasive cervical cancer cases [10], and it is suggested it has a biological advantage for viral transmission and persistence, as well as cell transformation [82]. Infection by HPV 16 requires micro-lesions in the host for the virions to access the cells of the basal layer. In these cells, considered as the infection reservoir, the viral genome remains as an episome with a low number of viral copies. The cells of the intermediate layers of the epithelium where HPV E6 and E7 are expressed promote cell transformation. The E6 oncoprotein interacts with multiple cellular proteins, affecting their function or promoting their degradation. For example, the interaction with ubiquitin ligase E6AP and subsequent degradation of p53 inhibits apoptosis, keratinocyte differentiation, and the response to interferons. Likewise, it has been observed that E6 activates factor c-Myc, telomerase hTERT, and the signaling pathways AKT, Wnt, Notch, and mTORC1 [83-85].

On the other hand, E7 binds to the proteins pRB, p107, and p130, promoting their degradation, which favors the progression of the cell cycle, stability and amplification of the genome, immortalization, and cellular transformation. Likewise, it suppresses the function of STAT1, activates the AKT signaling pathway, and binds to other proteins such as E2F1, Cullin2, and HDAC [83-85]. The viral cycle is completed when the viral genome is encapsulated and immature virions are released into the upper layer of the epithelium [86]. Furthermore, it is related to other cancers, such as head and neck, vulvar, vaginal, penile, and anal cancer [11]. It has been shown that the E6 and E7 oncoproteins are overexpressed in cells infected with HPV favoring tumorigenesis. Variants of the HPV 16 E6 and E7 oncoprotein have also been reported to regulate the expression of multiple genes involved in various cellular processes such as proliferation, differentiation, apoptosis, adhesion, angiogenesis, transcription, and protein translation [12,87,88].

\section{Variants of HPV 16}

The classification of HPV 16 variants has been made according to the distribution by their geographic origin [89]. In the analysis of their genome, the HPV 16 variants have been grouped into four main phylogenetic lineages: A (European-Asian, EAS), B (African 1, AF1), C (African 2, AF2), and D (North American/Asian American, NA/AA) [90]. The four lineages, in turn, have been subdivided into eleven sublineages: (1) A1, A2, A3 (European, E), A4 (Asian, As); (2) B1 (Afr1a), B2 (Afr1b); (3) C1 (Afr2a), C2 (Afr2b); and (4) D1 (North American, NA), D2 (Asian American 1, AA1), and D3 (Asian American 2, AA2) $[90,91]$. The sublineages have also been stratified into classes and subclasses [92]. The study of the variants of the specific genes E6 and E7 of HPV 16 has shown that the most frequent E6 variant is E-G350. However, AA-a showed a higher risk of developing cervical cancer, followed by E- A176/G350, AA-c, E-G350, and E-C188/G350 compared to the E-prototype [93]. On the other hand, the E7 variants have been studied to a lesser extent than the E6 variants. Some studies have reported, based on the conserved regions 
(CR) 1, CR2, and CR3 of E7, 4 variants in the CR1 domain [94,95], 5 in CR2 [94,96-99], and 14 in CR3 [94,95,100-103]. The most frequent variant, up to $70 \%$ in the Asian population, is the E7-G647 variant located in the CR2 domain [88,94].

\section{Mechanisms Involved in HPV 16 Variants-Mediated Metabolic Reprogramming}

Variants of HPV 16 have been associated with the oncogenic potential of the virus and the severity of cervical lesions [14,15]. It has been reported that the E6 and E7 oncoprotein of HR-HPV can promote metabolic reprogramming through increased activity of glycolytic enzymes and inhibition of the Krebs cycle and the respiratory chain to satisfy the energy requirements of cancer cells and achieve efficient viral replication [81,104]. Martínez-Ramírez and collaborators describe the enzymes and metabolic pathways altered by HR-HPV and report that HPV 16 increases glycolysis in oral squamous cell cancer. In lung cancer, GLUT1 transporter levels increase; in cervical cancer, glycolysis is due to increased glycolytic enzymes HKII, PFK, ENOA, PKM2, and LDHA. In contrast, oxidative phosphorylation (OXPHOS) is affected by HPV 16 in cervical cancer by modulating the mitochondrial structure and the release and increase of reactive oxygen species (ROS). This finding is explained by the inactivation of mitochondrial Complex III and ATP synthase and a decrease in glutathione (GSH) and superoxide dismutase 1 and 2 (SOD1 and 2) levels [81]. Additionally, it has been observed that E6 variants increase the expression of various genes, of which more than $60 \%$ correspond to genes associated with metabolic processes. [16]. The possibility exists that variants of the E6 and E7 oncoprotein of HPV 16 may favor metabolic reprogramming. Next, we will describe the role of HPV 16 variants in regulating the molecular mechanisms of cell metabolism in cancer.

\section{1. p53 Degradation}

Metabolic reprogramming in cancer is carried out by different molecular mechanisms related to p53, MYC, or HIF-1 $\alpha$ [105]. In recent years, variants of the E6 oncoprotein of HPV 16 have shown differences in their ability to bind p53 and induce its degradation [106], through the stability of the E6-E6AP-p53 complex [107]. HPV 16 variants AA, E, and Afr2a have been shown to reduce p53 levels in human keratinocytes (Figure 1), exhibiting a more significant effect than the E-prototype and E-G131 (R10G) variants [108-111]. The effect of the E-prototype variant on p53 degradation has been related to the polymorphism in codon 72 of p53, which results in an arginine genotype (CGC), conferring p53 greater susceptibility to being degraded by E6 (Figure 1) [112]. Higher expression of European E6 sublineage variants has also been reported to be related to greater p53 degradation compared to As sublineage variants [109]. Additionally, in a group of patients with cervical cancer, the presence of the polymorphism in codon 72 (homozygous arg/arg genotype of p53) with the E-prototype variant was related to the clinical status and the susceptibility for p53 to be degraded [113].

P53 is currently known to regulate glycolysis and oxidative phosphorylation (OXPHOS) [114]. It has been observed that it inhibits the entry of glucose into the cell by directly repressing the transcription of the glucose transporters GLUT1 and GLUT4 [115], in addition to inhibiting the translocation of GLUT1 by directly inducing the transcription of the Ras-related glycolysis inhibitor and calcium channel regulator (RRAD) [116]. It can also inhibit glycolysis by repressing the insulin receptor (INSR) expression, necessary in the translocation of GLUT4 to intracellular vesicles that are subsequently directed to the plasma membrane and, in turn, triggers a rapid increase in glucose absorption [117]. It negatively regulates HK2 and activates the expression of TP53 induced glycolysis regulatory phosphatase (TIGAR), reducing glycolytic activity and attenuating the activity of PFK1, leaving glucose-6-phosphate as a necessary substrate in the nucleotide synthesis in the pentose phosphate pathway [118,119]. Furthermore, it can inhibit glycolysis by reducing the expression of the glycolytic enzyme phosphoglycerate mutase (PGM), responsible for converting 3-phosphoglycerate (3PG) to 2-phosphoglycerate (2PG) during glycolysis [120] or by decreasing PKM2 (via the ubiquitin ligase Parkin, responsible for ubiquitinating 
PKM2) [114]. P53 has also been shown to inhibit lactate transport by repressing monocarboxylate transporter 1 (MCT1), causing lactate to accumulate and limit the glycolytic rate in cancer cells [121]. P53 positively regulates the entry of pyruvate into the mitochondria and the progression of TCA by increasing the amount of pyruvate carboxylase [122]. It has also been reported that p53 represses the function of transcription factors that induce the transcription of glycolysis regulatory enzymes, such as factor HIF1 [114]. It has been observed that p53 binds to the HIF- $1 \alpha /$ p300 complex to decrease its transcriptional activity; likewise, it also negatively regulates c-Myc [123,124]. In summary, the E6 variants of HPV 16 of the AA, E, and Afr2a sublineages can alter glucose metabolism by inducing p53 degradation, leading to increased expression of enzymes, transporters, and receptors involved in glycolysis such as GLUT1, GLUT4, INSR, HK2, TIGAR, PFK1, PKM2, MCT1, pyruvate carboxylase (PC) (Figure 1), and the positive regulation of the transcription factors HIF- $1 \alpha$ and c-Myc related to the transcription of genes involved in the glycolysis. Thus, the E6 variants of HPV 16 that induce a more significant degradation of p53 favor the increase of glycolysis in HPV-associated cancers.

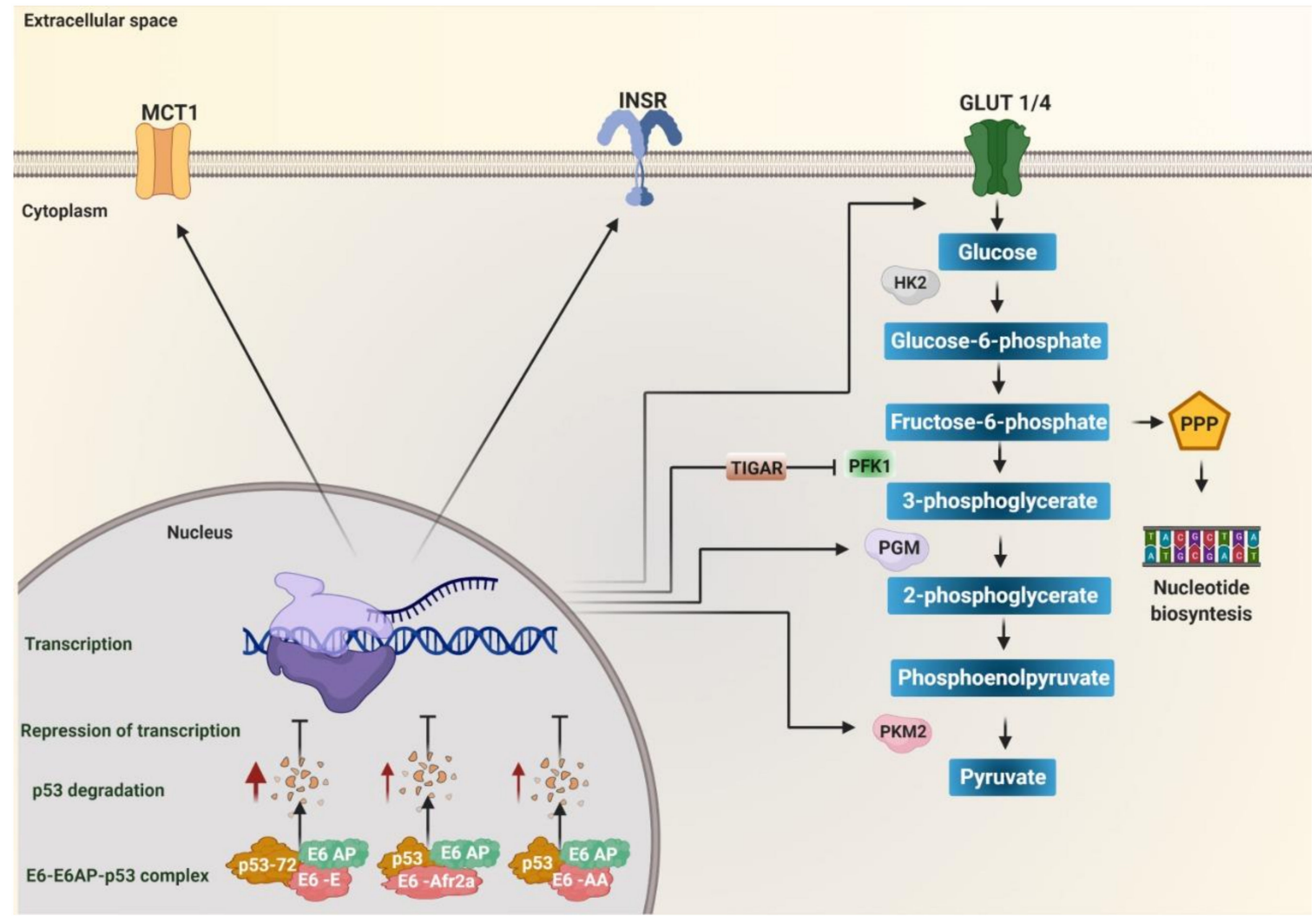

Figure 1. The degradation of p53 induced by E6 variants of human papillomavirus (HPV) 16 favors metabolic reprogramming. Variants of the European (E), African 2a (Afr2a), and Asian American (AA) sublineages decrease p53 levels through interaction with E6AP, increasing p53 degradation (red arrows), and avoiding transcriptional repression. p53 inhibits glycolysis by repressing transcription of the monocarboxylate transporter 1 (MCT1), the glucose transporters GLUT1 and GLUT4, the enzymes hexokinase 2 (HK2), phosphoglycerate mutase (PGM), pyruvate kinase 2 (PKM2), and TP53 induced glycolysis regulatory phosphatase (TIGAR). TIGAR decreases the activity of the enzyme phosphofructokinase 1 (PFK1) to target fructose-6-phosphate to the pentose phosphate (PPP) pathway. Insulin receptor (INSR) favors the translocation of GLUT4 to the membrane. Therefore, the absence of p53 due to its degradation by the effect of the variants of the E, Afr2a, and AA sublineages promotes glycolysis by activating the expression of the transporters GLUT1, GLUT4, MCT1, and the enzymes of the glycolytic pathway HK2, PGM, PKM2. Additionally, it targets fructose-6-phosphate to the PPP pathway via TIGAR for nucleotide synthesis. 


\section{2. $p R b$ Degradation}

It is currently known that in cancer cell lines, the HPV 16 E7 oncoprotein is located preferentially in the nucleus and, to a lesser extent, in the cytoplasm, which is related to the decrease in retinoblastoma protein $(\mathrm{pRb})$ levels [125]. Furthermore, dephosphorylated $\mathrm{pRb}$ has been reported to bind to the transcription factor E2F, inhibiting its transcriptional activity [126]. Factor E2F is activated when pRb is phosphorylated as it allows its release from the $\mathrm{pRb} / \mathrm{E} 2 \mathrm{~F}$ complex, thus binding to promoters of genes essential for cell cycle progression cdc2 and cyclin E $[126,127]$. Recently it has been reported that the variant A4 that has the N29S mutation in the E7 oncoprotein promotes more significant degradation of $\mathrm{pRb}$ compared to the variant designated A5 that possesses the L28F mutation (Figure 2) [128]. It has been reported that the mutation in variant $\mathrm{A} 4$ generates a new phosphate acceptor site for casein kinase II (CKII) that confers a greater phosphate-dependent interaction for $\mathrm{pRb}$ and that leads to its degradation in a greater proportion, compared to other E7 variants (Figure 2) [88,129]. The lack of $\mathrm{pRb}$ in tumors reduces oxidative metabolism, even when ATP levels do not decrease, increases the use of glutamine as a carbon source for obtaining energy, and increases the expression of genes involved in the synthesis of nucleotides such as dihydrofolate reductase (DHFR), thymidylate synthase (TS), ribonucleotide reductase (RNR), and thymidine kinase (TK), which are induced by E2F [130]. Considering that the A4 and A5 variants of HPV 16 E7 cause pRb degradation, it is suggested that these variants may be affecting metabolism as an alternative route that will allow them to obtain the necessary energy to maintain the replicative state of tumor cells.

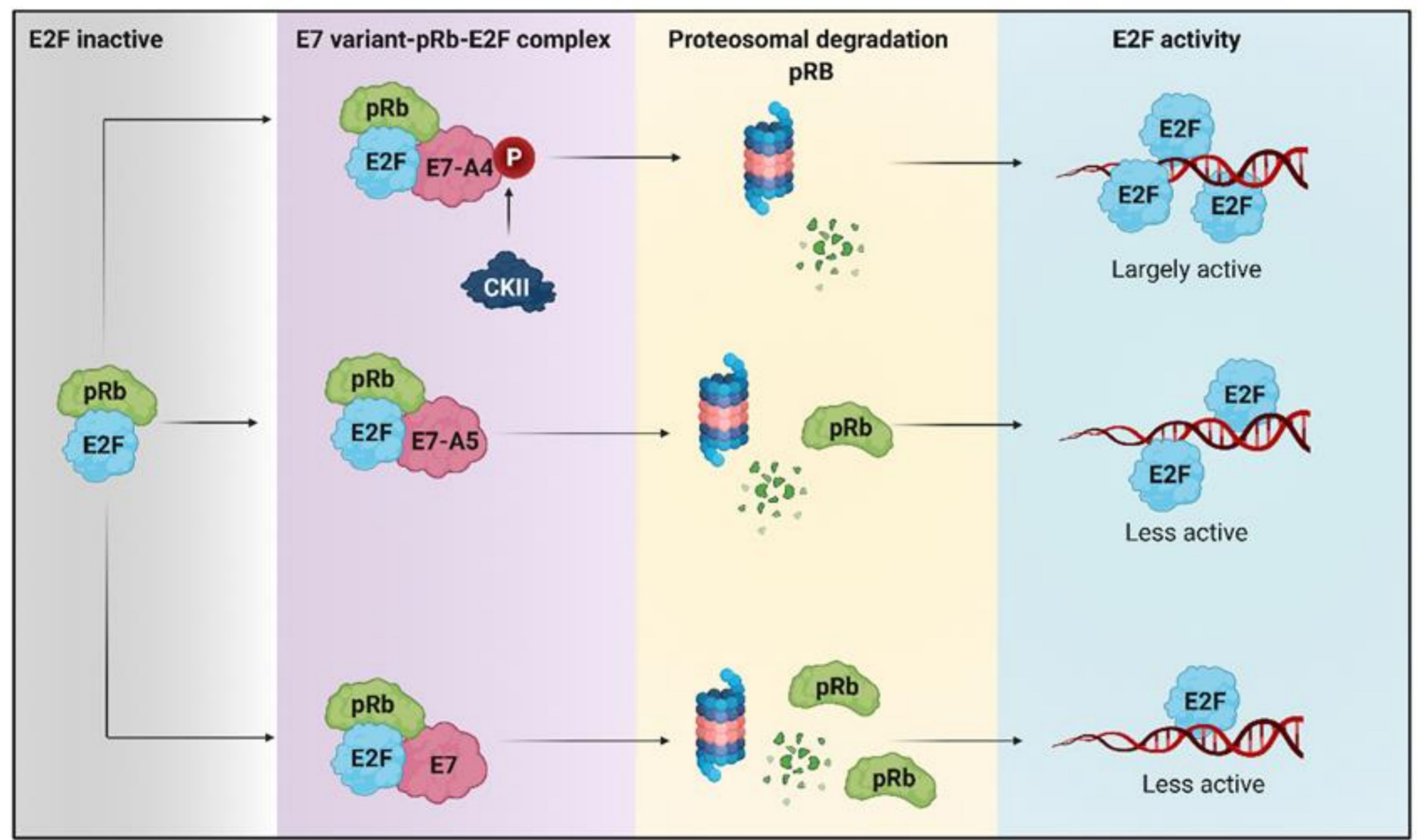

Figure 2. The degradation of retinoblastoma protein $(\mathrm{pRb})$ induced by HPV 16 E7 variants favors metabolic reprogramming. The hyperphosphorylated $\mathrm{pRb}$ repressor allows the release of E2F. The E7-A4 variant has a new phosphate acceptor site for casein kinase II (CKII) that promotes more significant degradation of pRb, compared to A5 and other E7 variants that degrade $\mathrm{pRb}$ to a lesser extent. Therefore, there is greater activation of E2F by the A4 variant than different E7 variants in which E2F is less active.

\subsection{Activation of c-Myc and Expression of Its Target Genes}

The transcription factor c-Myc is considered one of the most deregulated oncogenes in cancer [131]. It is known to be linked to alterations in cancer metabolism through the 
regulation of genes involved in the biogenesis of ribosomes and mitochondria, as well as genes involved in the metabolism of glucose, nucleotides, and glutamine [132]. The metabolic reprogramming induced by c-Myc is related to the increase of GLUT1, HK2, LDHA, PKM2, and ENO1 proteins of glycolytic metabolism and the increase of the glutamine transporters ASCT2 and glutaminase (GLS) enzyme (Figure 3) [133]. Under hypoxic conditions, c-Myc collaborates with active HIF1 by regulating pyruvate dehydrogenase kinase 1 (PDK1) levels, suppressing mitochondrial respiration, and promoting glucose conversion to lactate [132]. Variants exhibiting the R17I and Q21D mutations in the HPV 16 E6 oncoprotein have been shown to stabilize the E6-p53-E6AP complex [107]. Since the E6-p53-E6AP complex binds to the c-Myc protein [134], it is suggested that the variants of the E6 oncoprotein could be increasing the activity of c-Myc and the expression of its target genes involved in metabolism. On the other hand, the E-A126 variant that possesses the R8Q mutation in the E6 oncoprotein activates the Wnt/ $\beta$-catenin signaling pathway [135] promoting that $\beta$-catenin and PKM2 are translocated to the nucleus, inducing the expression of c-Myc (Figure 3) [136]. Therefore, the variants present the R17I, Q21D, and R8Q mutations in the E6 oncoprotein of HPV 16 could be favoring metabolic reprogramming, increased nucleotide synthesis, and glutaminolysis through c-Myc, HIF- $1 \alpha$, and pyruvate dehydrogenase kinase 1PDK1.

\subsection{Stability of HIF-1 $\alpha$ and Expression of Active HIF-1 Target Genes}

HPV 16 E6 has been reported to promote the hypoxia-induced Warburg effect by binding HIF- $1 \alpha$ and VHL by blocking the interaction between HIF- $1 \alpha$ and VHL [137]. Lack of interaction between HIF- $1 \alpha$ and VHL attenuates VHL-mediated ubiquitination of HIF- $1 \alpha$, preventing degradation of HIF- $1 \alpha$, suggesting that HPV 16 E6 plays an essential role in the regulation of the Warburg effect [138]. A decrease in the enzyme isocitrate dehydrogenase 1 (IDH1) and IDH2 has been observed in response to the AA/E7-prototype variant compared to E-prototype/E7-prototype [137], and a decrease in the expression levels of the VHL ubiquitin ligase by the Asian variant that has the D25E mutation in the E6 oncoprotein (Figure 3) [16]. IDH is necessary for the production of $\alpha-K G$, used for the hydroxylation of HIF- $1 \alpha$ under normoxia conditions, while VHL is a fundamental part of the degradation of HIF- $1 \alpha$ via the proteasome. Therefore, a decrease in IDH and VHL increases the stability of HIF- $1 \alpha$ [139]. Variants of the AA sublineage of the HPV 16 E6 oncoprotein have been shown to increase HIF- $1 \alpha$ levels in the keratinocyte nucleus under hypoxic conditions (Figure 3) [17]. According to the levels of HIF-1 $\alpha$ induced by AA sublineage variants, an increase in transcriptional activity has been observed under hypoxic conditions [17]. GLUT1 levels in cancer significantly increase in cells with AA sublineage variants (Figure 3) $[17,140,141]$. Additionally, HIF- $1 \alpha$ increases the levels of PKM2 and the transcriptional activator STAT3, which increases aerobic glycolysis and decreases mitochondrial activity (Figure 3) [142]. High levels and nuclear translocation of HIF- $1 \alpha$ are related to the ability of AA sublineage variants to enhance mitogen-activated protein kinases (MAPK)/extracellular signal-regulated kinase (ERK) $1 / 2$ phosphorylation (Figure 3) [17]. These data together indicate that variants of the AA and As sublineages of the HPV 16 E6 oncoprotein positively regulate the Warburg effect by increasing levels of metabolic proteins and transcriptional factors STAT3 and HIF- $1 \alpha$.

\subsection{Activation of Signaling Pathways That Regulate Glycolysis}

Aerobic glycolysis in cancer has been reported to occur downstream of cellular signaling pathways [143]. Among the signaling pathways that regulate aerobic glycolysis in cancer are members of the family of mitogen-activated protein kinases (MAPK), which in turn is divided into three subfamilies of MAPK: extracellular signal-regulated kinase (ERK), the N-terminal c-Jun kinase (JNK), and the p38 kinase. Members of the three MAPK subfamilies have been shown to regulate the redirection in energy production from glycolysis in malignant and highly proliferative cells by affecting the activity of key metabolic regulators, necessary for energy production in the development of cancer [143]. The MAPK 
signaling pathway is activated by the E-G350 (L83V) variant of the E6 oncoprotein of HPV 16. It is related to larger and more aggressive tumors compared to the E-prototype variant [144]. Variants of the AA sublineage have been reported to exhibit more significant expression of the MAP2K1 gene [145] that codes for MAPK1, also known as MEK1; a component of the RAS mitogen-activated protein kinase (MAPK) pathway, MAPK1 is a threonine/tyrosine kinase that activates ERK1 and promotes autophagy [146]. Autophagy in tumor cells is necessary to prevent energy crisis and maintain nucleotide reserves during starvation [147] by recycling macromolecules, thus providing bioenergetic and biosynthetic substrates TCA cycle, which maintains energy homeostasis and nucleotide levels [148]. Autophagy is increased to promote survival, growth, and malignant neoplasia autonomously in tumor cells [148]. Variants of the AA sublineage have a greater capacity to activate the signaling pathway: MAPK-ERK, MAPK-p38, and PI3K/AKT (Figure 3) [149]. It has been observed that the E-G350 variant and the variants of the AA sublineage of the E6 oncoprotein of HPV 16 affect the regulation of metabolic reprogramming in cancer, the EG350 variant through MAPK, and the variants of the sublineage AA by obtaining nutrients through MEK1/ERK1-activated autophagy and by activating MAPK-ERK, MAPK-p38, and PI3K/AKT signaling. The MAPK-p38 signaling pathway positively regulates GLUT1 and GLUT4 expression and glucose uptake $[150,151]$. The low activation of the AKT pathway is related to PKM2, ENO1, ENO2, and HK2 expression through the HIF-1/AKT signaling pathway [152]. On the other hand, it has been observed that the ERK and PI3K signaling pathways are necessary for the expression of LDH and pyruvate dehydrogenase kinase (PDK). However, the activation of PDK is also dependent on Src/JNK [153]. These data suggest that variants of the AA sublineage and the E-G350 variant of the E6 oncoprotein of HPV 16, both with the T350G mutation, play a crucial role in the reprogramming of glycolytic metabolism at the level of three critical components of pyruvate metabolism, $\mathrm{LDH}$, pyruvate dehydrogenase (PDH), and PDK, in which the entry of pyruvate to the TCA cycle is inhibited by being metabolized to lactate.

The Wnt signaling pathway has been related to the formation of malignant tumors such as breast, colon [154], and cervical cancer, where the Wnt pathway has been suggested as one of the main dysregulation pathways [155]. The HPV 16 variants that present the E-A126 (R8Q), E-G131 (R10G), E-G350 (L83V), and E-T245 (R48W) mutations in the E6 oncoprotein. These can hyperactivate the Wnt signaling pathway, being activated more by the variant presenting the R8Q mutation (Figure 3), followed by the variants showing the L83V, R10G, and R48W mutations [135]. The E-A126 (R8Q) variant was found to exhibit a greater effect on the activation of $\beta$-catenin transcription (Figure 3) [135]. The Wnt $/ \beta$ catenin pathway regulates the activation of the tyrosine kinase receptors that leads to the activation of the PI3K/AKT pathway, which leads to an increase in glucose metabolism, which in turn leads to the activation of the Warburg effect through HIF- $1 \alpha$, which in turn increases the expression of GLUT, HK, PKM2, LDH-A, and PDK, resulting in increased cytosolic pyruvate, of which most is converted to lactate and released to the extracellular environment, while a small part is converted to acetyl-CoA, which enters the TCA cycle and is converted to citrate to promote lipid and protein synthesis [136]. Furthermore, the Wnt/ $\beta$-catenin pathway has been shown to increase the Warburg effect by suppressing mitochondrial respiration by reducing cytochrome oxidase transcription, an essential enzyme for OXPHOS [154]. On the other hand, AA sublineage variants increase mTOR activation, which, like the Wnt/ $\beta$-catenin pathway, leads to energy metabolism activation through HIF-1 $\alpha$ [13]. 


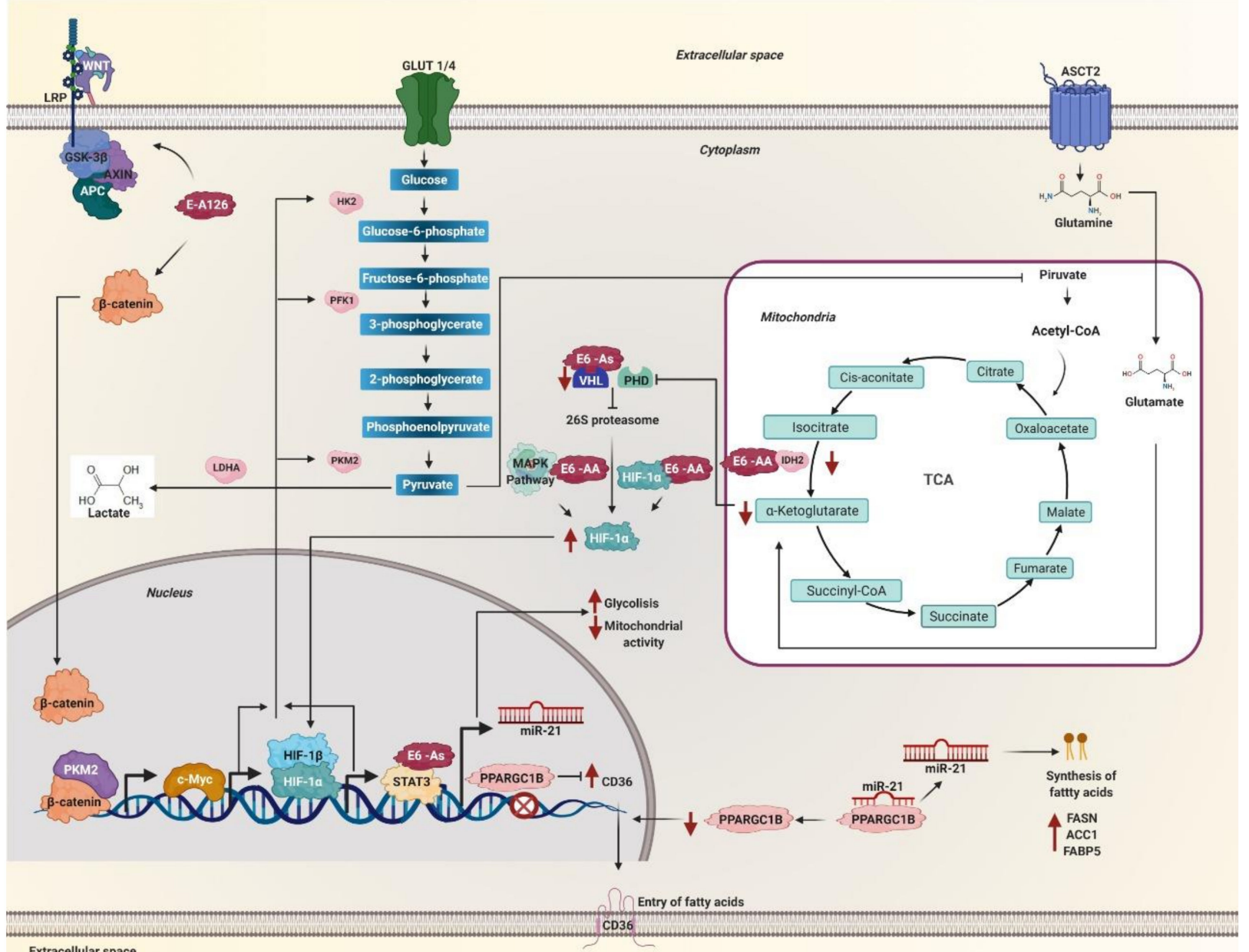

Figure 3. Metabolic reprogramming is mediated by HPV 16 E6 variants through c-Myc, hypoxia-inducible factor (HIF)- $1 \alpha$, WNT, and miR-21. The E6 variant E-A126 with the R8Q mutation promotes the glycolytic pathway by activating the Wnt/ $\beta$-catenin pathway. Variants of the AA sublineage activate the mitogen-activated protein kinases (MAPK) pathway that increases HIF- $1 \alpha$ levels. The protein $\beta$-catenin translocates to the nucleus accompanied by PKM 2 and induces the expression of c-Myc. These variants also decrease the levels of the isocitrate dehydrogenase 1 (IDH2) enzyme necessary to obtain $\alpha$-ketoglutarate, one of the substrates of the prolyl-4-hydroxylases (PHDs) enzymes. On the other hand, the As sublineage variants decrease the von Hippel Lindau (VHL) ubiquitin ligase levels, both enzymes are necessary for HIF- $1 \alpha$ to be degraded via the $26 \mathrm{~S}$ proteasome. Therefore, the variants of the AA and As sublineages increase the levels of HIF- $1 \alpha$, avoiding its degradation via the proteasome. Consequently, HIF- $1 \alpha$ stabilizes and translocates to the nucleus. Both HIF- $1 \alpha$ and c-Myc increase the levels of glycolysis enzymes such as hexokinase 2 (HK2), phosphofructokinase 1 (PFK1), pyruvate kinase M2 (PKM2), lactate dehydrogenase A (LDH-A), as well, lactate levels increase. The STAT3 activator increases glycolysis, decreases mitochondrial activity and allows the transcription of miR-21, which is also positively regulated by variants of the As sublineage. MiR-21 inhibits the PPARGC1B messenger. The levels of the CD36 transcriptional repressor PPARGC1B decrease and allow the expression and translocation of CD36. In this way, miR-21 regulates the entry and synthesis of fatty acids in the cell by the effect of the variants of the AA and As sublineages.

\subsection{Overexpression of $m i R-21$}

MicroRNAs (miRNAs) are small RNAs of 20 to 24 nucleotides that control gene expression by binding to the 3'UTR, 5'UTR, or non-coding regions of messenger RNA (mRNA), which leads to degradation of mRNA or inhibition of protein synthesis $[156,157]$. Studies in cervical cancer cells transfected with variants of the Asian sublineage of the E6 oncoprotein of HPV 16 observed a 2- to 3-fold higher expression of miR-21 (Figure 3) compared to the E-prototype variant [158]. The increased expression levels of miR-21 have been associated 
with STAT3 expression, the transcriptional activator of miR-21 (Figure 3) [158]. miR-21 has also been reported to promote carcinogenesis by regulating fatty acid metabolism by promoting increased cellular lipid content, including cellular phospholipid content, neutral lipid content, and cellular triglyceride content [159], by increasing the expression of the lipid and fatty acid receptor CD36, since it targets PPARGC1B, a target of miR-21, a transcriptional repressor of CD36 $[159,160]$. Furthermore, miR-21 is involved in the increase of crucial lipid metabolic enzymes such as fatty acid synthase (FASN), acetyl-CoA carboxylase 1 (ACC1), and fatty acid-binding protein 5 (FABP5) [159]. However, the mechanism by which it favors the increase of these enzymes is still unknown. These data suggest that carcinogenesis promoted by the variants of the As sublineage is increased since they promote the expression of miR-21 favoring the entry and synthesis of fatty acids, necessary for the production of energy and synthesis of cell membranes, as well as the expression of key enzymes of lipid metabolism (Figure 3).

\subsection{Regulation of Metabolic Enzymes}

During the cell cycle, cells experience a series of events that require a significant supply of energy. It has been observed that during the G1 phase and the synthesis phase, or S phase, energy requirements are increased due to the synthesis of proteins, nucleic acids, and lipids. Therefore, glycolysis and pyruvate production is increased [161]. It has been reported that cultures of primary human foreskin keratinocytes (PHFK) transfected with the E7-prototype variant and those of the AA sublineage of the E6 oncoprotein of HPV 16 exhibit a more significant proportion of cells in the G1 phase, higher levels of enzymes of the metabolism of glucose, and low levels of TCA enzymes [137]. A decrease in the enzyme isocitrate dehydrogenase 1 and 2 (IDH1, IDH2) has also been observed in PHFK transfected with the bicistron containing the variant of the AA and E7-prototype sublineage (AA/E7-prototype) compared to the bicistron with the variants E-prototype/E7prototype [137]. Likewise, higher GAPDH and PKM2 were observed in PHFK with AA/E7-prototype variants compared to E-prototype/E7-prototype (Figure 4), and low levels of phosphoglucomutase enzymes-2 and aldo-ketoreductase with the bicistron of the AA/E7-prototype variants compared to E-prototype/E7-prototype [137]. These data suggest that the oncogenicity of the variants of the AA sublineage of the E6 oncoprotein of HPV 16 is related to the Warburg effect by increasing glucose metabolism enzymes (Figure 4) [6] and decreasing enzymes of the tricarboxylic acid cycle as the IDH necessary for the production of $\alpha$-ketoglutarate used in the hydroxylation of HIF- $1 \alpha$ for its subsequent degradation via proteasome under normoxic conditions. In this sense, the decrease in IDH favors an increase in the stability of HIF- $1 \alpha$, allowing the expression of its target genes involved in glycolytic metabolism [139], a hallmark of cancer [6,27]. It was also reported that in PHFK with variants of the AA sublineage of the E6 oncoprotein of HPV 16, glucose entry into the cell increases (Figure 4). It was observed that PHFKs with variants of the AA sublineage are capable of internalizing up to 1.65 times more glucose compared to PHFK with the E-prototype variant, which is accompanied by an increase in glucose consumption and a greater secretion of lactate compared to PHFK containing the E-prototype (Figure 4) [17]. Lactate excretion into the extracellular space is considered part of the tumor microenvironment. It is related to extracellular proteolysis, which results in an acid-resistant phenotype necessary for cancer cell migration and metastasis [162].

On the other hand, AA sublineage variants increase the expression of CAIX compared to the E-prototype; this effect is greater in the presence of E7-prototype (Figure 4) [163]. The CAIX gene is highly expressed in response to hypoxia and is considered a general marker of tumor hypoxia, considered part of the tumor microenvironment in numerous solid tumors $[164,165]$. This suggests that the expression of CAIX is directly related to the oncogenic potential of the AA sublineage variants of the E6 oncoprotein, where there is a more significant increase compared to the E-prototype [163]. One of the ways that could also be participating in the positive regulation of glycolysis through the AA sublineage variant is by binding to the gamma- 2 subunit of the protein kinase activated by $5^{\prime}$-AMP 
(PRKAG2) [13], a regulator key to vigorous metabolism that activates energy production pathways and inhibits energy-consuming processes [13].

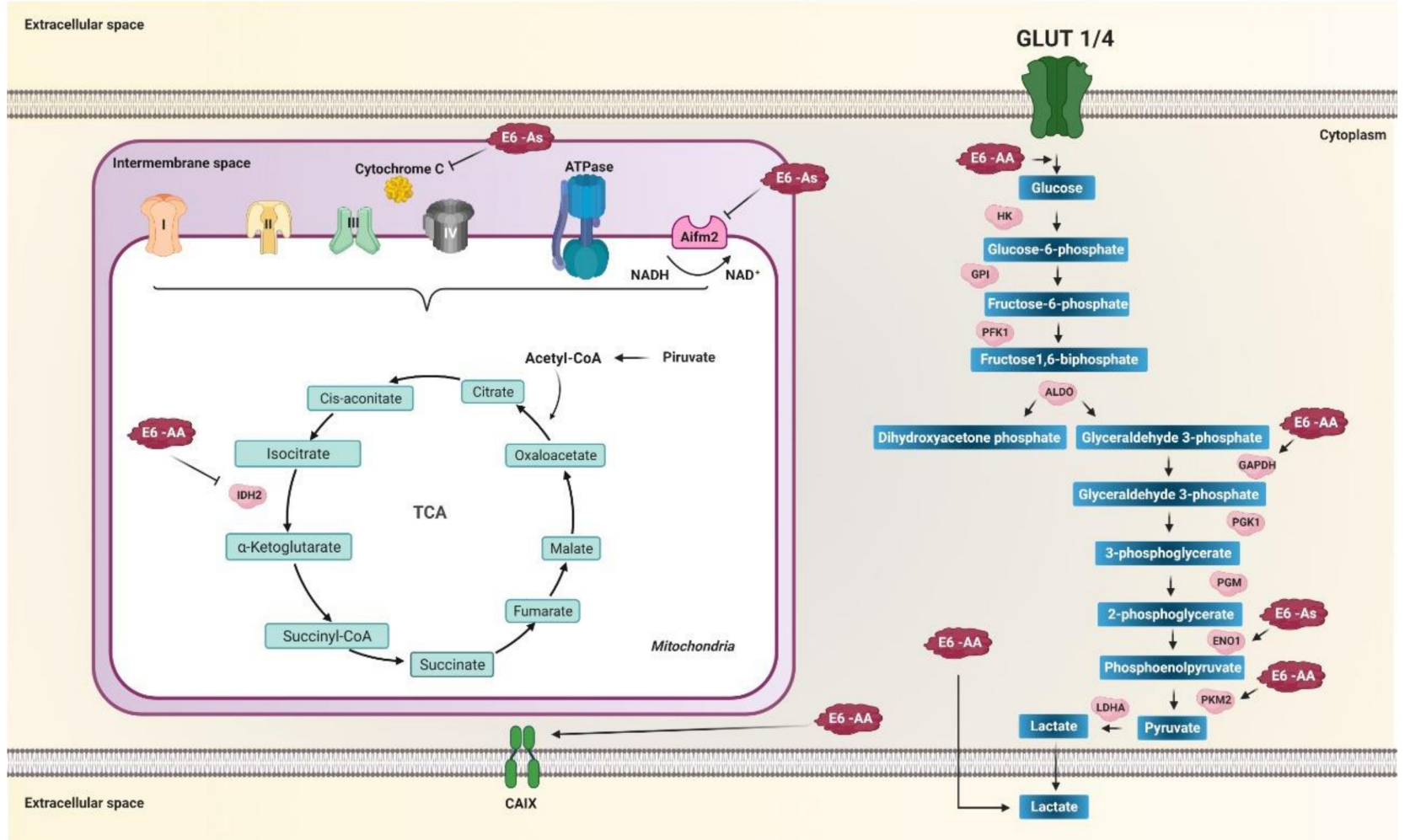

Figure 4. E6 variants of HPV 16 regulate the activity of enzymes related to metabolic reprogramming. Variants of the AA sublineage increase glucose entry into the cell, increase glyceraldehyde-3-phosphate dehydrogenase (GAPDH), PKM2, and increase lactate release. Variants of the As sublineage increase enolase 1 (ENO1) levels. Mitochondrial metabolism is decreased by variants of the AA and As sublineages. Variants of the AA sublineage decrease IDH2 in the tricarboxylic acid cycle (TCA), whereas variants of the As sublineage decrease AIFM2 and cytochrome c in the electron transport chain (ETC). Variants of the AA sublineage increase the carbonic IX (CAIX) enzyme levels, essential for balancing the pH of the tumor microenvironment induced by aerobic glycolysis. Arrows in black indicate activation and positive regulation as appropriate. The thick black arrows indicate the increase in the product of the enzymatic reaction. Arrows T indicate inhibition.

On the other hand, the Asian variant of E6, containing the amino acid change D25E in the E6 oncoprotein, negatively regulates the expression of the AIFM2 protein [16], known as apoptosis-inducing factor mitochondria associated 2, which contains a domain oxidoreductase NADH [166]. It has also been observed that the variant of the AA sublineage binds to cytochrome $C$ [13] and could be interfering at levels such as the Asian variant D25E [13,16,167], which also increases the expression levels of ENO1 (Figure 4) [16]. The low levels of AIFM2 and cytochrome $\mathrm{C}$, as well as the increase in the expression of ENO1 induced by the variant AA and As, may affect the reduction of oxidative phosphorylation, favoring the production of energy through aerobic glycolysis, one of the main characteristics of metabolic reprogramming in cancer. Furthermore, the As variant has been shown to decrease the levels of the enzyme GSTP1 (glutathione S transferase Pi 1) [168], a critical cytosolic enzyme of phase II detoxification metabolism [169]. Low levels of GSTP1 are associated with DNA damage from reactive oxygen species and drug resistance in cancer [169], suggesting that the As variant of HPV 16 may negatively regulate phase II detoxification metabolism. Consequently, ROS levels and DNA damage that favors integrating the viral genome into the cellular genome can be increased.

The integration of the HPV 16 genome into the host genome is associated with carcinogenesis, not only because of the overexpression of E6 and E7 but also because it can induce 
the several host overexpression mRNAs [170]. As observed in epithelial samples with the integrated viral genome of the variants of the AA sublineage of the E6 oncoprotein of HPV 16 , there is an overexpression of the SLC26A2 gene that encodes a solute transporter [171]. The SLC26A2 gene belongs to the family of SLC26 genes that encode solute transporters responsible for transporting sulfate $\left(\mathrm{SO}_{2}{ }^{-}\right), \mathrm{Cl}^{-}$, and oxalate [172]. Oxalate can be produced by epithelial cells and be present as free oxalic acid or in salts such as sodium, calcium, or potassium oxalates [173-176]. High oxalate levels may be related to the transformation of normal to tumor cells, increasing proliferation [177] and mitochondrial damage, as well as altering basal proton output and mitochondrial oxygen consumption linked to ATP production [178] through damage to mitochondrial proteins [179]. These data suggest that variants of the AA sublineage of the HPV 16 E6 oncoprotein might have a different effect on dysregulation of mitochondrial metabolism and increased aerobic glycolysis through integration and overexpression of SLC26A2. Table 1 summarizes the effect that the E6 and E7 variants of HPV 16 has on metabolic reprogramming in cancer.

Table 1. Effect of HPV 16 E6 and E7 variants on metabolic reprogramming in cancer.

\begin{tabular}{|c|c|c|c|c|c|}
\hline Oncoprotein & Sublineage & Nucleotide or Protein Variant & Effect on Protein or Signaling Pathway & Effect on Metabolism & Reference \\
\hline \multirow{10}{*}{ E6 } & \multirow{7}{*}{ Europeo } & E-prototype & $\downarrow \mathrm{p} 53$ & 4 glycolysis & [108-112] \\
\hline & & R17I & \multirow{2}{*}{$4 \mathrm{c}-\mathrm{Myc}$ expression and activation } & \multirow{2}{*}{$\begin{array}{l}\text { 4 glycolytic metabolism } \\
\text { 4nucleotide synthesis } \\
\text { Aglutaminolysis }\end{array}$} & \multirow{2}{*}[107,132-136]{} \\
\hline & & Q21D & & & \\
\hline & & E-A126 (R8Q) & $\begin{array}{l}4 \mathrm{c}-\mathrm{Myc} \text { expression and activation } \\
4 \mathrm{Wnt} / \beta \text {-catenin signaling pathway activation }\end{array}$ & $\begin{array}{l}\text { A glycolytic metabolism } \\
\text { Anucleotide synthesis } \\
\text { †glutaminolysis } \\
\text { \&Warburg effect } \\
\checkmark \text { mitochondrial respiration }\end{array}$ & {$[107,132-136,154]$} \\
\hline & & E-G131 (R10G) & $\begin{array}{l}\text { vp53 } \\
4 \mathrm{Wnt} / \beta \text {-catenin signaling pathway activation }\end{array}$ & $\begin{array}{l}\text { A glycolysis } \\
\text { A Warburg effect }{ }^{4} \text { mitochondrial respiration }\end{array}$ & {$[108-112,135,136,154]$} \\
\hline & & E-T245 (R48W) & $\uparrow \mathrm{Wnt} / \beta$-catenin signaling pathway activation & $\begin{array}{l}\text { A glycolytic metabolism } \\
4 \text { Warburg effect } \\
\text { vmitochondrial respiration }\end{array}$ & {$[135,136,154]$} \\
\hline & & E-G350 (L83V) & $\begin{array}{l}4 \mathrm{MAPK} \text { signaling pathway activation } \\
4 \mathrm{Wnt} / \beta \text {-catenin signaling pathway activation }\end{array}$ & $\begin{array}{l}\text { 4 autophagy } \\
\text { \$glycolytic metabolism } \\
\text { } \text { Warburg effect } \\
\downarrow \text { mitochondrial respiration }\end{array}$ & {$[135,136,144,150,151,154]$} \\
\hline & Asian & As (D25E) & $\begin{array}{l}\text { 4 HIF-1 } \alpha \text { stability } \\
\text { 4STAT3 expression } \\
\text { 4miR-21 expression } \\
\text { † AIFM2 expression } \\
\text { 4ENO1 expression } \\
\text { cytochrome liberation } \\
\text { vglutathione S transferase Pi } 1 \text { (GSTP1) levels }\end{array}$ & $\begin{array}{l}\uparrow \text { Warburg effect } \\
\downarrow \text { mitochondrial respiration } \\
\text { ^fatty acid synthesis } \\
\text { ^lipid metabolism } \\
\text { voxidative phosphorylation } \\
\downarrow \text { phase II detox metabolism }\end{array}$ & $\begin{array}{l}{[13,16,17,137,139-142,158-} \\
160,168]\end{array}$ \\
\hline & Asian-American & AA (Q14H/H78Y/L83V) & 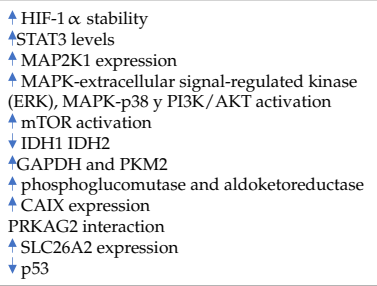 & $\begin{array}{l}\text { A autophagy } \\
\text { A glucose uptake } \\
\text { A glycolytic metabolism and Warburg effect } \\
\text { i internalization of glucose into the cell } \\
\text { \& oxalate levels, mitochondrial damage }\end{array}$ & $\begin{array}{l}{[6,13,16,17,108-112,137,139-} \\
142,145,149-151,163,171]\end{array}$ \\
\hline & African & Afr2a(R10I/Q14D/H78Y) & $\downarrow \mathrm{p} 53$ & 4 glycolysis & [108-112] \\
\hline \multirow{2}{*}{ E7 } & & A4 (N29S) & \multirow{2}{*}{$\downarrow \mathrm{pRb}$} & \multirow{2}{*}{$\begin{array}{l}\checkmark \text { oxidative metabolism } \\
\text { A glutaminolysis } \\
\text { A nucleotide synthesis }\end{array}$} & \multirow{2}{*}[88,128-130]{} \\
\hline & & A5 (L28F) & & & \\
\hline
\end{tabular}

Up or down arrows indicate the increase or decrease, respectively.

\section{Conclusions}

Metabolic reprogramming is one of the hallmarks of cancer. There is a considerable increase in glycolysis and lactate production even in the presence of oxygen, a phenomenon known as the "Warburg effect". Likewise, there is an increase in the synthesis of fatty acids and glutaminolysis. The E6 and E7 oncoproteins of HPV 16 can promote metabolic reprogramming through increased activity of glycolytic enzymes and decreased oxidative metabolism to meet the energy requirements of cancer cells and achieve efficient viral replication. The E6 and E7 variants of HPV 16 present a different oncogenic potential for cancer development through various mechanisms that promote metabolic reprogramming. The variants of the E, As, AA, and Afr2a sublineages, which present the R10G, R48W, D25E, Q14H, H78Y, L83V, R8Q, R17I, and Q21D mutations of the E6 oncoprotein of HPV 
16 favor metabolic reprogramming, increasing the entry of glucose and glycolysis due to the increase in the levels of GLUT1 and the enzymes of the glycolytic pathway such as HK2, GAPDH, ENO1, PKM2, LDH-A, decreasing oxidative metabolism due to the decrease in the levels of proteins such as PDK, IDH1, IDH2, Aifm2, and cytochrome C, likewise stimulating the glutaminolysis pathway by increasing the ASCT2 transporter and the GLS enzyme, as well as the entry and synthesis of fatty acids, necessary for energy production and synthesis of cell membranes, processes mediated by the degradation of p53, increased levels of c-Myc and the stability of HIF-1 $\alpha$, activation of the Wnt pathway, and overexpression of $\mathrm{miR}-21$.

On the other hand, the E7 A4 variant promotes metabolic reprogramming by increasing glutaminolysis and nucleotide synthesis through $\mathrm{pRb}$ degradation and E2F activation. The mechanisms described show that HPV 16 variants regulate metabolism in cancer through metabolic reprogramming; however, further research is necessary to understand how variations in the nucleotide and amino acid sequence of E6 and E7 of HPV 16 may be favoring metabolic reprogramming. It is required to carry out more detailed analyses on the interaction of the variants of the E6 and E7 oncoproteins of HPV 16 with proteins involved in altered metabolic pathways during metabolic reprogramming to understand the development of this pathology and to be able to propose new markers and strategies in the HPV 16 cancer therapy. The information presented in this review shows that the E6 and E7 variants of HPV 16 play a crucial role in metabolic reprogramming, and the detection and identification of the viral type are of great importance in patients with precancerous lesions or cancers associated with infection by HPV, as metabolic reprogramming is an essential hallmark in carcinogenesis. Likewise, the enzymes or proteins involved in energy metabolism affected by these variants could be studied as possible therapeutic targets or diagnostic and prognostic markers in cancers associated with HPV infection.

Author Contributions: A.A.-I. designed and performed the literature review and wrote the manuscript; N.N.-T., H.J.-W., M.A.M.-C., D.N.M.-C., A.E.Z.-G., M.O.-F., R.D.-M., F.I.T.-R., D.G.S.-F., and B.I.-A. conducted the literature review and wrote the manuscript; J.O.-O., reviewed the manuscript, development, and design of the research. All authors have read and agree to the final version of the manuscript.

Funding: This research was supported by SEP-CONACYT CB-2017-2018 A1-S-43704.

Conflicts of Interest: The authors declare no conflict of interest.

\section{References}

1. Hanahan, D.; Weinberg, R.A. The Hallmarks of Cancer. Cell 2000, 100, 57-70. [CrossRef]

2. Sonnenschein, C.; Soto, A.M. The aging of the 2000 and 2011 Hallmarks of Cancer reviews: A critique. J. Biosci. 2013, 38, $651-663$. [CrossRef] [PubMed]

3. DeBerardinis, R.J.; Lum, J.J.; Hatzivassiliou, G.; Thompson, C.B. The Biology of Cancer: Metabolic Reprogramming Fuels Cell Growth and Proliferation. Cell Metab. 2008, 7, 11-20. [CrossRef] [PubMed]

4. Semenza, G.L.; Artemov, D.; Bedi, A.; Bhujwalla, Z.; Chiles, K.; Feldser, D.; Laughner, E.; Ravi, R.; Simons, J.; Taghavi, P.; et al. "The metabolism of tumours": 70 years later. Novartis Found. Symp. 2001, 240, 251-260.

5. Lu, J. The Warburg metabolism fuels tumor metastasis. Cancer Metastasis Rev. 2019, 13. [CrossRef]

6. Heiden, M.G.V.; Cantley, L.C.; Thompson, C.B. Understanding the warburg effect: The metabolic requirements of cell proliferation. Science 2009, 324, 1029-1033. [CrossRef]

7. De Martel, C.; Ferlay, J.; Franceschi, S.; Vignat, J.; Bray, F.; Forman, D.; Plummer, M. Global burden of cancers attributable to infections in 2008: A review and synthetic analysis. Lancet Oncol. 2012, 13, 607-615. [CrossRef]

8. Mesri, E.A.; Feitelson, M.A.; Munger, K. Human viral oncogenesis: A cancer hallmarks analysis. Cell Host Microbe 2014, 15, 266-282. [CrossRef]

9. Guan, P.; Howell-Jones, R.; Li, N.; Bruni, L.; De Sanjosé, S.; Franceschi, S.; Clifford, G.M. Human papillomavirus types in 115,789 HPV-positive women: A meta-analysis from cervical infection to cancer. Int. J. Cancer 2012, 131, 2349-2359. [CrossRef]

10. Arbyn, M.; De Sanjosé, S.; Saraiya, M.; Sideri, M.; Palefsky, J.; Lacey, C.; Gillison, M.; Bruni, L.; Ronco, G.; Wentzensen, N.; et al. EUROGIN 2011 roadmap on prevention and treatment of HPV-related disease. Int. J. Cancer 2012, 131, 1969-1982. [CrossRef] [PubMed]

11. Cogliano, V.; Baan, R.; Straif, K.; Grosse, Y.; Secretan, B.; El Ghissassi, F. Carcinogenicity of human papillomaviruses. Lancet Oncol. 2005, 6, 204. [CrossRef] 
12. Zacapala-Gómez, A.E.; Del Moral-Hernández, O.; Villegas-Sepúlveda, N.; Hidalgo-Miranda, A.; Romero-Córdoba, S.L.; BeltránAnaya, F.O.; Leyva-Vázquez, M.A.; del Carmen Alarcón-Romero, L.; Illades-Aguiar, B. Changes in global gene expression profiles induced by HPV 16 E6 oncoprotein variants in cervical carcinoma C33-A cells. Virology 2016, 488, 187-195. [CrossRef] [PubMed]

13. Dayer, G.; Masoom, M.L.; Togtema, M.; Zehbe, I. Virus-Host Protein-Protein Interactions between Human Papillomavirus 16 E6 A1 and D2/D3 Sub-Lineages: Variances and Similarities. Int. J. Mol. Sci. 2020, 21, 7980. [CrossRef] [PubMed]

14. Zehbe, I.; Voglino, G.; Delius, H.; Wilander, E.; Tommasino, M. Risk of cervical cancer and geographical variations of human papillomavirus 16 E6 polymorphisms. Lancet 1998, 352, 1441-1442. [CrossRef]

15. Kämmer, C.; Tommasino, M.; Syrjänen, S.; Delius, H.; Hebling, U.; Warthorst, U.; Pfister, H. Variants of the long control region and the E6 oncogene in European human papillomavirus type 16 isolates: Implications for cervical disease. Br. J. Cancer 2002, 86, 269-273. [CrossRef] [PubMed]

16. Jang, M.; Rhee, J.E.; Jang, D.H.; Kim, S.S. Gene Expression Profiles are Altered in Human Papillomavirus-16 E6 D25E-Expressing Cell Lines. Virol. J. 2011, 8, 453. [CrossRef] [PubMed]

17. Cuninghame, S.; Jackson, R.; Lees, S.J.; Zehbe, I. Two common variants of human papillomavirus type 16 E6 differentially deregulate sugar metabolism and hypoxia signalling in permissive human keratinocytes. J. Gen. Virol. 2017, 98, 2310-2319. [CrossRef] [PubMed]

18. Ancey, P.B.; Contat, C.; Meylan, E. Glucose transporters in cancer-From tumor cells to the tumor microenvironment. FEBS J. 2018, 285, 2926-2943. [CrossRef]

19. Akram, M. Mini-review on glycolysis and cancer. J. Cancer Educ. 2013, 28, 454-457. [CrossRef] [PubMed]

20. Fernie, A.R.; Carrari, F.; Sweetlove, L.J. Respiratory metabolism: Glycolysis, the TCA cycle and mitochondrial electron transport. Curr. Opin. Plant Biol. 2004, 7, 254-261. [CrossRef]

21. Liberti, M.V.; Locasale, J.W. The Warburg Effect: How Does it Benefit Cancer Cells? Trends Biochem. Sci. 2016, 41, 211-218. [CrossRef]

22. Carracedo, A.; Cantley, L.C.; Pandolfi, P.P. Cancer metabolism: Fatty acid oxidation in the limelight. Nat. Rev. Cancer 2013, 13, 227-232. [CrossRef]

23. Katagiri, M.; Nakamura, M. Reappraisal of the 20th-century version of amino acid metabolism. Biochem. Biophys. Res. Commun. 2003, 312, 205-208. [CrossRef]

24. Rustin, P.; Bourgeron, T.; Parfait, B.; Chretien, D.; Munnich, A.; Rotig, A. Inborn errors of the Krebs cycle: A group of unusual mitochondrial diseases in human. Biochim. Biophys. Acta Mol. Basis Dis. 1997, 1361, 185-197. [CrossRef]

25. Anderson, N.M.; Mucka, P.; Kern, J.G.; Feng, H. The emerging role and targetability of the TCA cycle in cancer metabolism. Protein Cell 2018, 9, 216-237. [CrossRef]

26. Warburg, O. On the Origin of Cancer Cells. Science 1956, 123, 309-314. [CrossRef] [PubMed]

27. Hanahan, D.; Weinberg, R.A. Hallmarks of cancer: The next generation. Cell 2011, 144, 646-674. [CrossRef] [PubMed]

28. Ward, P.S.; Thompson, C.B. Metabolic Reprogramming: A Cancer Hallmark Even Warburg Did Not Anticipate. Cancer Cell 2012, 21, 297-308. [CrossRef] [PubMed]

29. Hanahan, D.; Folkman, J. Patterns and emerging mechanisms of the angiogenic switch during tumorigenesis. Cell 1996, 86, 353-364. [CrossRef]

30. Gritti, G.; Cortelezzi, A.; Bucciarelli, P.; Rezzonico, F.; Lonati, S.; La Marca, S.; Silvestris, I.; Federici, A.B. Circulating and progenitor endothelial cells are abnormal in patients with different types of von Willebrand disease and correlate with markers of angiogenesis. Am. J. Hematol. 2011, 86, 650-656. [CrossRef]

31. Birnbaum, M.J.; Haspel, H.C.; Rosen, O.M. Transformation of Rat Fibroblasts by FSV Rapidly Increases Glucose Transporter Gene Transcription. Science 1987, 235, 1495-1498. [CrossRef]

32. Jones, R.G.; Thompson, C.B. Tumor suppressors and cell metabolism. Genes Dev. 2009, 23, 537-548. [CrossRef] [PubMed]

33. Hsu, P.P.; Sabatini, D.M. Cancer cell metabolism: Warburg and beyond. Cell 2008, 134, 703-707. [CrossRef] [PubMed]

34. Cuezva, J.M.; De Heredia, M.L.; Santamaría, G.; Chamorro, M.; Kim, H.; Krajewska, M.; Krajewski, S.; Zapata, J.M.; Marusawa, H.; Reed, J.C. The bioenergetic signature of cancer: A marker of tumor progression. Cancer Res. 2002, 62, 6674-6681. [PubMed]

35. Xu, Y.; Miriyala, S.; Fang, F.; Bakthavatchalu, V.; Noel, T.; Schell, D.M.; Wang, C.; St Clair, W.H.; St Clair, D.K. Manganese superoxide dismutase deficiency triggers mitochondrial uncoupling and the Warburg effect. Oncogene 2015, 34, 4229-4237. [CrossRef] [PubMed]

36. Xu, S.; Catapang, A.; Braas, D.; Stiles, L.; Doh, H.M.; Lee, J.T.; Graeber, T.G.; Damoiseaux, R.; Shirihai, O.; Herschman, H.R. A precision therapeutic strategy for hexokinase 1-null, hexokinase 2-positive cancers. Cancer Metab. 2018, 6, 7. [CrossRef]

37. Minchenko, O.; Opentanova, I.; Caro, J. Hypoxic regulation of the 6-phosphofructo-2-kinase/fructose-2,6- bisphosphatase gene family (PFKFB-1-4) expression in vivo. FEBS Lett. 2003, 554, 264-270. [CrossRef]

38. Okar, D.A.; Manzano, A.; Navarro-Sabatè, A.; Riera, L.; Bartrons, R.; Lange, A.J. PFK-2/FBPase-2: Maker and breaker of the essential biofactor fructose-2,6-bisphosphate. Trends Biochem. Sci. 2001, 26, 30-35. [CrossRef]

39. Chang, Y.C.; Yang, Y.C.; Tien, C.P.; Yang, C.J.; Hsiao, M. Roles of Aldolase Family Genes in Human Cancers and Diseases. Trends Endocrinol. Metab. 2018, 29, 549-559. [CrossRef]

40. Lee, N.C.W.; Carella, M.A.; Papa, S.; Bubici, C. High Expression of Glycolytic Genes in Cirrhosis Correlates With the Risk of Developing Liver Cancer. Front. Cell Dev. Biol. 2018, 6, 1-16. [CrossRef] 
41. Tokunaga, K.; Nakamura, Y.; Sakata, K.; Fujimori, K.; Ohkubo, M.; Sawada, K.; Sakiyama, S. Enhanced expression of a GAPDH gene in human lung cancers. Cancer Res. 1987, 47, 5616-5619. [PubMed]

42. Ripple, M.O.; Wilding, G. Alteration of Glyceraldehyde-3-phosphate Dehydrogenase Activity and Messenger RNA Content by Androgen in Human Prostate Carcinoma Cells. Cancer Res. 1995, 55, 4234-4236. [PubMed]

43. Schek, N.; Hall, B.L.; Finn, O.J. Increased Glyceraldehyde-3-phosphate Dehydrogenase Gene Expression in Human Pancreatic Adenocarcinoma. Cancer Res. 1988, 48, 6354-6359. [PubMed]

44. Kim, J.W.; Kim, S.J.; Han, S.M.; Paik, S.Y.; Hur, S.Y.; Kim, Y.W.; Lee, J.M.; Namkoong, S.E. Increased glyceraldehyde-3-phosphate dehydrogenase gene expression in human cervical cancers. Gynecol. Oncol. 1998, 71, 266-269. [CrossRef] [PubMed]

45. Zhong, X.Y.; Yuan, X.M.; Xu, Y.Y.; Yin, M.; Yan, W.W.; Zou, S.W.; Wei, L.M.; Lu, H.J.; Wang, Y.P.; Lei, Q.Y. CARM1 Methylates GAPDH to Regulate Glucose Metabolism and Is Suppressed in Liver Cancer. Cell Rep. 2018, 24, 3207-3223. [CrossRef] [PubMed]

46. Sun, S.; Liang, X.; Zhang, X.; Liu, T.; Shi, Q.; Song, Y.; Jiang, Y.; Wu, H.; Jiang, Y.; Lu, X.; et al. Phosphoglycerate kinase-1 is a predictor of poor survival and a novel prognostic biomarker of chemoresistance to paclitaxel treatment in breast cancer. Br. J. Cancer 2015, 112, 1332-1339. [CrossRef]

47. Ahmad, S.S.; Glatzle, J.; Bajaeifer, K.; Bühler, S.; Lehmann, T.; Königsrainer, I.; Vollmer, J.P.; Sipos, B.; Ahmad, S.S.; Northoff, H.; et al. Phosphoglycerate kinase 1 as a promoter of metastasis in colon cancer. Int. J. Oncol. 2013, 43, 586-590. [CrossRef] [PubMed]

48. Zieker, D.; Königsrainer, I.; Tritschler, I.; Löffler, M.; Beckert, S.; Traub, F.; Nieselt, K.; Bühler, S.; Weller, M.; Gaedcke, J.; et al. Phosphoglycerate kinase 1 a promoting enzyme for peritoneal dissemination in gastric cancer. Int. J. Cancer 2010, 126, 1513-1520. [CrossRef]

49. Fiorillo, A.; Petrosino, M.; Ilari, A.; Pasquo, A.; Cipollone, A.; Maggi, M.; Chiaraluce, R.; Consalvi, V. The phosphoglycerate kinase 1 variants found in carcinoma cells display different catalytic activity and conformational stability compared to the native enzyme. PLoS ONE 2018, 13, e199191. [CrossRef]

50. Semenza, G.L. Defining the role of hypoxia-inducible factor 1 in cancer biology and therapeutics. Oncogene 2010, 29, 625-634. [CrossRef]

51. Capello, M.; Ferri-Borgogno, S.; Riganti, C.; Chattaragada, M.S.; Principe, M.; Roux, C.; Zhou, W.; Petricoin, E.F.; Cappello, P.; Novelli, F. Targeting the Warburg effect in cancer cells through ENO1 knockdown rescues oxidative phosphorylation and induces growth arrest. Oncotarget 2016, 7. [CrossRef]

52. Chaneton, B.; Gottlieb, E. Rocking cell metabolism: Revised functions of the key glycolytic regulator PKM2 in cancer. Trends Biochem. Sci. 2012, 37, 309-316. [CrossRef]

53. Israelsen, W.J.; Dayton, T.L.; Davidson, S.M.; Fiske, B.P.; Hosios, A.M.; Bellinger, G.; Li, J.; Yu, Y.; Sasaki, M.; Horner, J.W.; et al. PKM2 isoform-specific deletion reveals a differential requirement for pyruvate kinase in tumor cells. Cell 2013, 155, 397. [CrossRef] [PubMed]

54. Feng, Y.; Xiong, Y.; Qiao, T.; Li, X.; Jia, L.; Han, Y. Lactate dehydrogenase A: A key player in carcinogenesis and potential target in cancer therapy. Cancer Med. 2018, 7, 6124-6136. [CrossRef] [PubMed]

55. Doherty, J.R.; Cleveland, J.L. Targeting lactate metabolism for cancer therapeutics Find the latest version: Review series Targeting lactate metabolism for cancer therapeutics. J. Clin. Investig. 2013, 123, 3685-3692. [CrossRef] [PubMed]

56. Vaupel, P.; Mayer, A.; Höckel, M. Tumor Hypoxia and Malignant Progression. Exp. Oncol. 2004, 381, 335-354. [CrossRef]

57. Vaupel, P.; Kalllinowski, F.; Okunieff, P. Blood Flow, Oxygen and Nutrient Supply, and Metabolic Microenvironment of Human Tumors: A Review. Cancer Res. 1989, 49, 6449-6465.

58. Brizel, D.M.; Scully, S.P.; Harrelson, J.M.; Layfield, L.J.; Bean, J.M.; Prosnitz, L.R.; Dewhirst, M.W. Tumor oxygenation predicts for the likelihood of distant metastases in human soft tissue sarcoma. Cancer Res. 1996, 56, 941-943.

59. Helmlinger, G.; Yuan, F.; Marc, D.; Jain, R.K. Interstitial pH and pO2 gradients in solid tumors in vivo: High-resolution measurements reveal a lack of correlation. Nat. Med. 1997, 3, 177-182. [CrossRef]

60. Wykoff, C.C.; Beasley, N.J.P.; Watson, P.H.; Turner, K.J.; Pastorek, J.; Sibtain, A.; Wilson, G.D.; Turley, H.; Talks, K.L.; Maxwell, P.H.; et al. Hypoxia-inducible expression of tumor-associated carbonic anhydrases. Cancer Res. 2000, 60, 7075-7083. [PubMed]

61. Mole, D.R.; Blancher, C.; Copley, R.R.; Pollard, P.J.; Gleadle, J.M.; Ragousis, J.; Ratcliffe, P.J. Genome-wide association of hypoxiainducible factor (HIF)- $1 \alpha$ and HIF- $2 \alpha$ DNA binding with expression profiling of hypoxia-inducible transcripts. J. Biol. Chem. 2009, 284, 16767-16775. [CrossRef]

62. Xia, X.; Lemieux, M.E.; Li, W.; Carroll, J.S.; Brown, M.; Liu, X.S.; Kung, A.L. Integrative analysis of HIF binding and transactivation reveals its role in maintaining histone methylation homeostasis. Proc. Natl. Acad. Sci. USA 2009, 106, 4260-4265. [CrossRef]

63. Liao, D.; Johnson, R.S. Hypoxia: A key regulator of angiogenesis in cancer. Cancer Metastasis Rev. 2007, 26, 281-290. [CrossRef]

64. Bindra, R.S.; Crosby, M.E.; Glazer, P.M. Regulation of DNA repair in hypoxic cancer cells. Cancer Metastasis Rev. 2007, 26, 249-260. [CrossRef]

65. Chan, D.A.; Giaccia, A.J. Hypoxia, gene expression, and metastasis. Cancer Metastasis Rev. 2007, 26, 333-339. [CrossRef] [PubMed]

66. Sullivan, R.; Graham, C.H. Hypoxia-driven selection of the metastatic phenotype. Cancer Metastasis Rev. 2007, 26, 319-331. [CrossRef]

67. Swietach, P.; Vaughan-Jones, R.D.; Harris, A.L. Regulation of tumor pH and the role of carbonic anhydrase 9. Cancer Metastasis Rev. 2007, 26, 299-310. [CrossRef] 
68. Chiche, J.; Ilc, K.; Laferrière, J.; Trottier, E.; Dayan, F.; Mazure, N.M.; Brahimi-Horn, M.C.; Pouysségur, J. Hypoxia-inducible carbonic anhydrase IX and XII promote tumor cell growth by counteracting acidosis through the regulation of the intracellular pH. Cancer Res. 2009, 69, 358-368. [CrossRef] [PubMed]

69. Semenza, G.L. Regulation of cancer cell metabolism by hypoxia-inducible factor 1. Semin. Cancer Biol. 2009, 19, 12-16. [CrossRef]

70. Wang, G.L.; Jiang, B.H.; Rue, E.A.; Semenza, G.L. Hypoxia-inducible factor 1 is a basic-helix-loop-helix-PAS heterodimer regulated by cellular O2 tension. Proc. Natl. Acad. Sci. USA 1995, 92, 5510-5514. [CrossRef] [PubMed]

71. Iommarini, L.; Porcelli, A.M.; Gasparre, G.; Kurelac, I. Non-Canonical Mechanisms Regulating Hypoxia-Inducible Factor 1 Alpha in Cancer. Front. Oncol. 2017, 7, 286. [CrossRef]

72. Kaelin, W.G.; Ratcliffe, P.J. Oxygen Sensing by Metazoans: The Central Role of the HIF Hydroxylase Pathway. Mol. Cell 2008, 30, 393-402. [CrossRef]

73. Lee, K.; Zhang, H.; Qian, D.Z.; Rey, S.; Liu, J.O.; Semenza, G.L. Acriflavine inhibits HIF-1 dimerization, tumor growth, and vascularization KangAe. Med. Sci. 2009, 106, 17910-17915.

74. Ke, Q.; Costa, M. Hypoxia-Inducible Factor-1 (HIF-1). Mol. Pharmacol. 2006, 70, 1469-1480. [CrossRef]

75. Soga, T. Cancer metabolism: Key players in metabolic reprogramming. Cancer Sci. 2013, 104, 275-281. [CrossRef]

76. Masoud, G.N.; Li, W. HIF-1 $\alpha$ pathway: Role, regulation and intervention for cancer therapy. Acta Pharm. Sin. B 2015, 5, 378-389. [CrossRef] [PubMed]

77. Koyasu, S.; Kobayashi, M.; Goto, Y.; Hiraoka, M.; Harada, H. Regulatory mechanisms of hypoxia-inducible factor 1 activity: Two decades of knowledge. Cancer Sci. 2018, 109, 560-571. [CrossRef]

78. Kalyanaraman, B. Teaching the basics of cancer metabolism: Developing antitumor strategies by exploiting the differences between normal and cancer cell metabolism. Redox Biol. 2017, 12, 833-842. [CrossRef]

79. Li, H.; Li, X.; Ge, X.; Jia, L.; Zhang, Z.; Fang, R.; Yang, J.; Liu, J.; Peng, S.; Zhou, M.; et al. MiR-34b-3 and miR-449a inhibit malignant progression of nasopharyngeal carcinoma by targeting lactate dehydrogenase A. Oncotarget 2016, 7, 54838-54851. [CrossRef]

80. Mamtimin, B.; Hizbulla, M.; Kurbantay, N.; You, L.; Yan, X.; Upur, H. An magnetic resonance-based plasma metabonomic investigation on abnormal Savda in different complicated diseases. J. Tradit. Chin. Med. 2014, 34, 166-172. [CrossRef]

81. Martínez-Ramírez, I.; Carrillo-García, A.; Contreras-Paredes, A.; Ortiz-Sánchez, E.; Cruz-Gregorio, A.; Lizano, M. Regulation of cellular metabolism by high-risk human papillomaviruses. Int. J. Mol. Sci. 2018, 19, 1839. [CrossRef] [PubMed]

82. Bosch, F.X.; Burchell, A.N.; Schiffman, M.; Giuliano, A.R.; de Sanjose, S.; Bruni, L.; Tortolero-Luna, G.; Kjaer, S.K.; Muñoz, N. Epidemiology and Natural History of Human Papillomavirus Infections and Type-Specific Implications in Cervical Neoplasia. Vaccine 2008, 26. [CrossRef]

83. Doorbar, J.; Quint, W.; Banks, L.; Bravo, I.G.; Stoler, M.; Broker, T.R.; Stanley, M.A. The biology and life-cycle of human papillomaviruses. Vaccine 2012, 30, F55-F70. [CrossRef] [PubMed]

84. Harden, M.E.; Munger, K. Human papillomavirus molecular biology. Mutat. Res. Rev. Mutat. Res. 2017, 772, 3-12. [CrossRef] [PubMed]

85. Estêvão, D.; Costa, N.R.; Gil da Costa, R.M.; Medeiros, R. Hallmarks of HPV carcinogenesis: The role of E6, E7 and E5 oncoproteins in cellular malignancy. Biochim. Biophys. Acta Gene Regul. Mech. 2019, 1862, 153-162. [CrossRef] [PubMed]

86. Moody, C.A. Mechanisms by which HPV Induces a Replication Competent Environment in Differentiating Keratinocytes. Viruses 2017, 19, 261. [CrossRef]

87. Mirabello, L.; Yeager, M.; Yu, K.; Clifford, G.M.; Xiao, Y.; Zhu, B.; Cullen, M.; Boland, J.F.; Wentzensen, N.; Nelson, C.W.; et al. HPV16 E7 Genetic Conservation Is Critical to Carcinogenesis. Cell 2017, 170, 1164-1174.e6. [CrossRef] [PubMed]

88. Zine El Abidine, A.; Tomaić, V.; Bel Haj Rhouma, R.; Massimi, P.; Guizani, I.; Boubaker, S.; Ennaifer, E.; Banks, L. A naturally occurring variant of HPV-16 E7 exerts increased transforming activity through acquisition of an additional phospho-acceptor site. Virology 2017, 500, 218-225. [CrossRef]

89. Calleja-Macias, I.E.; Kalantari, M.; Huh, J.; Ortiz-Lopez, R.; Rojas-Martinez, A.; Gonzalez-Guerrero, J.F.; Williamson, A.L.; Hagmar, B.; Wiley, D.J.; Villarreal, L.; et al. Genomic diversity of human papillomavirus-16, 18, 31, and 35 isolates in a Mexican population and relationship to European, African, and Native American variants. Virology 2004, 319, 315-323. [CrossRef]

90. Burk, R.D.; Harari, A.; Chen, Z. Human papillomavirus genome variants. Virology 2013, 445, 232-243. [CrossRef]

91. Cornet, I.; Gheit, T.; Franceschi, S.; Vignat, J.; Burk, R.D.; Sylla, B.S.; Tommasino, M.; Clifford, G.M. Human Papillomavirus Type 16 Genetic Variants: Phylogeny and Classification Based on E6 and LCR. J. Virol. 2012, 86, 6855-6861. [CrossRef]

92. Huertas-Salgado, A.; Martín-Gámez, D.C.; Moreno, P.; Murillo, R.; Bravo, M.M.; Villa, L.; Molano, M. E6 molecular variants of human papillomavirus (HPV) type 16: An updated and unified criterion for clustering and nomenclature. Virology 2011, 410, 201-215. [CrossRef]

93. Ortiz-Ortiz, J.; Alarcón-Romero, L.D.C.; Jiménez-López, M.A.; Garzón-Barrientos, V.H.; Calleja-Macías, I.; Barrera-Saldaña, H.A.; Leyva-Vázquez, M.A.; Illades-Aguiar, B. Association of human papillomavirus 16 E6 variants with cervical carcinoma and precursor lesions in women from Southern Mexico. Virol. J. 2015, 12, 29. [CrossRef]

94. Wu, Y.; Chen, Y.; Li, L.; Yu, G.; He, Y.; Zhang, Y. Analysis of mutations in the E6/E7 oncogenes and L1 gene of human papillomavirus 16 cervical cancer isolates from China. J. Gen. Virol. 2006, 87, 1181-1188. [CrossRef] [PubMed]

95. Tsakogiannis, D.; Kyriakopoulou, Z.; Amoutzias, G.; Ruether, I.G.A.; Dimitriou, T.G.; Panotopoulou, E.; Markoulatos, P. Identification of novel E6-E7 sequence variants of human papillomavirus 16. Arch. Virol. 2013, 158, 821-828. [CrossRef] [PubMed] 
96. Swan, D.C.; Rajeevan, M.; Tortolero-Luna, G.; Follen, M.; Tucker, R.A.; Unger, E.R. Human papillomavirus type 16 E2 and E6/E7 variants. Gynecol. Oncol. 2005, 96, 695-700. [CrossRef] [PubMed]

97. Lee, C.W.; Bae, J.H.; Lee, S.J.; Ho, E.M.; Lee, I.H.; Park, Y.G.; Park, J.S. Distribution of human papillomavirus type 16 E6 and E7 gene variants in the progression of cervical dysplasia in Korean women. J. Obstet. Gynaecol. Res. 2011, 37, 1320-1326. [CrossRef]

98. Shang, Q.; Wang, Y.; Fang, Y.; Wei, L.; Chen, S.; Sun, Y.; Li, B.; Zhang, F.; Gu, H. Human papillomavirus type 16 variant analysis of E6, E7, and L1 genes and long control region in identification of cervical carcinomas in patients in northeast China. J. Clin. Microbiol. 2011, 49, 2656-2663. [CrossRef]

99. Boumba, L.M.A.; Assoumou, S.Z.; Hilali, L.; Mambou, J.V.; Moukassa, D.; Ennaji, M.M. Genetic variability in E6 and E7 oncogenes of human papillomavirus Type 16 from Congolese cervical cancer isolates Cancer centers in low- and middle-income countries. Infect. Agent. Cancer 2015, 10, 15. [CrossRef] [PubMed]

100. Hu, X.; Pang, T.; Guo, Z.; Pontén, J.; Nistér, M.; Afink, G.B. Oncogene lineages of human papillomavirus type 16 E6, E7 and E5 in preinvasive and invasive cervical squamous cell carcinoma. J. Pathol. 2001, 195, 307-311. [CrossRef]

101. Choi, B.-S.; Kim, S.S.; Yun, H.; Jang, D.H.; Lee, J.-S. Distinctive Distribution of HPV16 E6 D25E and E7 N29S Intratypic Asian Variants in Korean Commercial Sex Workers. J. Med. Virol. 2007, 79, 426-430. [CrossRef]

102. Ding, T.; Wang, X.; Ye, F.; Cheng, X.; Lu, W.; Xie, X. Distribution of human papillomavirus 16 e6/e7 variants in cervical cancer and intraepithelial neoplasia in chinese women. Int. J. Gynecol. Cancer 2010, 20, 66. [CrossRef]

103. Yang, L.; Yang, H.; Wu, K.; Shi, X.; Ma, S.; Sun, Q. Prevalence of HPV and Variation of HPV 16/HPV 18 E6/E7 Genes in Cervical Cancer in Women in South West China Lijuan. J. Med. Virol. Preval. 2014, 86, 1926-1936. [CrossRef]

104. Chandel, V.; Raj, S.; Kumar, P.; Gupta, S.; Dhasmana, A.; Kesari, K.K.; Ruokolainen, J.; Mehra, P.; Das, B.C.; Kamal, M.A.; et al. Metabolic regulation in HPV associated head and neck squamous cell carcinoma. Life Sci. 2020, 258, 118236. [CrossRef] [PubMed]

105. Cairns, R.A.; Harris, I.S.; Mak, T.W. Regulation of cancer cell metabolism. Nat. Rev. Cancer 2011, 11, 85-95. [CrossRef]

106. Stöppler, M.C.; Ching, K.; Stöppler, H.; Clancy, K.; Schlegel, R.; Icenogle, J. Natural variants of the human papillomavirus type 16 E6 protein differ in their abilities to alter keratinocyte differentiation and to induce p53 degradation. J. Virol. 1996, 70, 6987-6993. [CrossRef]

107. Rader, J.S.; Tsaih, S.W.; Fullin, D.; Murray, M.W.; Iden, M.; Zimmermann, M.T.; Flister, M.J. Genetic variations in human papillomavirus and cervical cancer outcomes. Int. J. Cancer 2019, 144, 2206-2214. [CrossRef] [PubMed]

108. Zehbe, I.; Richard, C.; DeCarlo, C.A.; Shai, A.; Lambert, P.F.; Lichtig, H.; Tommasino, M.; Sherman, L. Human papillomavirus 16 E6 variants differ in their dysregulation of human keratinocyte differentiation and apoptosis. Virology 2009, 383, 69-77. [CrossRef] [PubMed]

109. Hang, D.; Gao, L.; Liu, Y.; Ke, Y. Functional Effects of Sequence Variations in the E6 and E2 Genes of Human Papillomavirus 16 European and Asian Variants. J. Med. Virol. 2014, 86, 618-626. [CrossRef]

110. Yi, J.W.; Jang, M.; Kim, S.J.; Kim, S.S.; Rhee, J.E. Degradation of p53 by natural variants of the E6 protein of human papillomavirus type 16. Oncol. Rep. 2013, 29, 1617-1622. [CrossRef] [PubMed]

111. Bartholomeusz, A.; Locarnini, S. Associated With Antiviral Therapy. Antivir. Ther. 2006, 55, 52-55. [CrossRef]

112. Storey, A.; Thomas, M.; Kalita, A.; Harwood, C.; Gardiol, D.; Mantovani, F.; Breuer, J.; Leigh, I.M.; Matlashewski, G.; Banks, L. Role of a p53 polymorphism in the development of human papilloma-virus- associated cancer. Nature 1998, 393, 229-234. [CrossRef] [PubMed]

113. Brady, C.S.; Duggan-Keen, M.F.; Davidson, J.A.; Varley, J.M.; Stern, P.L. Human papillomavirus type 16 E6 variants in cervical carcinoma: Relationship to host genetic factors and clinical parameters. J. Gen. Virol. 1999, 80, 3233-3240. [CrossRef]

114. Gomes, A.S.; Ramos, H.; Soares, J.; Saraiva, L. P53 and Glucose Metabolism: An Orchestra To Be Directed in Cancer Therapy. Pharmacol. Res. 2018, 131, 75-86. [CrossRef]

115. Schwartzenberg-Bar-Yoseph, F.; Armoni, M.; Karnieli, E. The Tumor Suppressor p53 Down-Regulates Glucose Transporters GLUT1 and GLUT4 Gene Expression. Cancer Res. 2004, 64, 2627 LP-2633 LP. [CrossRef] [PubMed]

116. Zhang, C.; Liu, J.; Wu, R.; Liang, Y.; Lin, M.; Liu, J.; Chan, C.S.; Hu, W.; Feng, Z. Tumor suppressor p53 negatively regulates glycolysis stimulated by hypoxia through its target RRAD. Oncotarget 2014, 5, 5535-5546. [CrossRef]

117. Webster, N.J.G.; Resnik, J.L.; Reichart, D.B.; Strauss, B.; Haas, M.; Seely, B.L. Repression of the insulin receptor promoter by the tumor suppressor gene product p53: A possible mechanism for receptor overexpression in breast cancer. Cancer Res. 1996, 56, 2781-2788. [PubMed]

118. Bensaad, K.; Cheung, E.C.; Vousden, K.H. Modulation of intracellular ROS levels by TIGAR controls autophagy. EMBO J. 2009, 28, 3015-3026. [CrossRef] [PubMed]

119. Li, H.; Jogl, G. Structural and biochemical studies of TIGAR (TP53-induced glycolysis and apoptosis regulator). J. Biol. Chem. 2009, 284, 1748-1754. [CrossRef] [PubMed]

120. Kondoh, H.; Lleonart, M.E.; Gil, J.; Wang, J.; Degan, P.; Peters, G. Glycolytic Enzymes Can Modulate Cellular Life Span. Cancer Res. 2005, 177-186.

121. Boidot, R.; Veǵran, F.; Meulle, A.; Le Breton, A.; Dessy, C.; Sonveaux, P.; Lizard-Nacol, S.; Feron, O. Regulation of monocarboxylate transporter MCT1 expression by p53 mediates inward and outward lactate fluxes in tumors. Cancer Res. 2012, 72, 939-948. [CrossRef] [PubMed]

122. Contractor, T.; Harris, C.R. p53 negatively regulates transcription of the pyruvate dehydrogenase kinase Pdk2. Cancer Res. 2012, 72, 560-567. [CrossRef] [PubMed] 
123. Blagosklonny, M.V.; An, W.G.; Romanova, L.Y.; Trepel, J.; Fojo, T.; Neckers, L. P53 Inhibits Hypoxia-Inducible Factor-Stimulated Transcription. J. Biol. Chem. 1998, 273, 11995-11998. [CrossRef] [PubMed]

124. Ho, J.S.L.; Ma, W.; Mao, D.Y.L.; Benchimol, S. p53-Dependent Transcriptional Repression of c-myc Is Required for G1 Cell Cycle Arrest. Mol. Cell. Biol. 2005, 25, 7423-7431. [CrossRef] [PubMed]

125. Fiedler, M.; Müller-Holzner, E.; Viertler, H.; Widschwendter, A.; Laich, A.; Pfister, G.; Spoden, G.A.; Jansen-Dürr, P.; Zwerschke, W. High level HPV-16 E7 oncoprotein expression correlates with reduced pRb-levels in cervical biopsies. FASEB J. 2004, 18, 1120-1122. [CrossRef]

126. Seville, L.; Shah, N.; Westwell, A.; Chan, W. Modulation of pRb/E2F Functions in the Regulation of Cell Cycle and in Cancer. Curr. Cancer Drug Targets 2005, 5, 159-170. [CrossRef]

127. Wells, J.; Boyd, K.E.; Fry, C.J.; Bartley, S.M.; Farnham, P.J. Target Gene Specificity of E2F and Pocket Protein Family Members in Living Cells. Mol. Cell. Biol. 2000, 20, 5797-5807. [CrossRef] [PubMed]

128. Hirose, Y.; Onuki, M.; Tenjimbayashi, Y.; Yamaguchi-Naka, M.; Mori, S.; Tasaka, N.; Satoh, T.; Morisada, T.; Iwata, T.; Kiyono, T.; et al. Whole-Genome Analysis of Human Papillomavirus Type 16 Prevalent in Japanese Women with or without Cervical Lesions. Viruses 2019, 11, 350. [CrossRef]

129. Choo, K.B.; Wang, T.S.; Huang, C.J. Analysis of relative binding affinity of E7-pRB of human papillomavirus 16 clinical variants using the yeast two-hybrid system. J. Med. Virol. 2000, 61, 298-302. [CrossRef]

130. Nicolay, B.N.; Dyson, N.J. The multiple connections between pRB and cell metabolism. Curr. Opin. Cell Biol. 2013, 25, 735-740. [CrossRef]

131. Stine, Z.E.; Walton, Z.E.; Altman, B.J.; Hsieh, A.L.; Dang, C.V. MYC, metabolism, and cancer. Cancer Discov. 2015, 5, 1024-1039. [CrossRef] [PubMed]

132. Dang, C.V.; Le, A.; Gao, P. MYC-induced cancer cell energy metabolism and therapeutic opportunities. Clin. Cancer Res. 2009, 15, 6479-6483. [CrossRef] [PubMed]

133. Hsieh, A.L.; Walton, Z.E.; Altman, B.J.; Stine, Z.E.; Dang, C.V. MYC and metabolism on the path to cancer. Semin. Cell Dev. Biol. 2015, 43, 11-21. [CrossRef] [PubMed]

134. Type, P.; Protein, E.; Kinoshita, T.; Shirasawa, H.; Shino, Y.; Moriya, H. Transactivation of Prothymosin a and c-mycPromoters. Virology 1997, 61, 53-61.

135. Zehbe, I.; Lichtig, H.; Westerback, A.; Lambert, P.F.; Tommasino, M.; Sherman, L. Rare human papillomavirus 16 E6 variants reveal significant oncogenic potential. Mol. Cancer 2011, 10, 77. [CrossRef]

136. Vallée, A.; Lecarpentier, Y.; Guillevin, R.; Vallée, J.N. Aerobic glycolysis in amyotrophic lateral sclerosis and Huntington's disease. Rev. Neurosci. 2018, 29, 547-555. [CrossRef] [PubMed]

137. Richard, C.; Lanner, C.; Naryzhny, S.N.; Sherman, L.; Lee, H.; Lambert, P.F.; Zehbe, I. The immortalizing and transforming ability of two common human papillomavirus 16 E6 variants with different prevalences in cervical cancer. Oncogene 2010, 29, 3435-3445. [CrossRef] [PubMed]

138. Guo, Y.; Meng, X.; Ma, J.; Zheng, Y.; Wang, Q.; Wang, Y.; Shang, H. Human papillomavirus 16 E6 contributes HIF-1 $\alpha$ induced warburg effect by attenuating the VHL-HIF-1 $\alpha$ interaction. Int. J. Mol. Sci. 2014, 15, 7974-7986. [CrossRef]

139. Semenza, G.L. HIF-1: Upstream and downstream of cancer metabolism. Curr. Opin. Genet. Dev. 2010, 20, 51-56. [CrossRef]

140. Rudlowski, C.; Becker, A.J.; Schroder, W.; Rath, W.; Büttner, R.; Moser, M. GLUT1 Messenger RNA and Protein Induction Relates to the Malignant Transformation of Cervical Cancer. Am. J. Clin. Pathol. 2003, 120, 691-698. [CrossRef]

141. Carvalho, K.C.; Cunha, I.W.; Rocha, R.M.; Ayala, F.R.; Cajaíba, M.M.; Begnami, M.D.; Vilela, R.S.; Paiva, G.R.; Andrade, R.G.; Soares, F.A. GLUT1 expression in malignant tumors and its use as an immunodiagnostic marker. Clinics 2011, 66, 965-972. [CrossRef]

142. Demaria, M.; Camporeale, A.; Poli, V. STAT3 and metabolism: How many ways to use a single molecule? Int. J. Cancer 2014, 135, 1997-2003. [CrossRef] [PubMed]

143. Papa, S.; Choy, P.M.; Bubici, C. The ERK and JNK pathways in the regulation of metabolic reprogramming. Oncogene 2019, 38, 2223-2240. [CrossRef] [PubMed]

144. Chakrabarti, O.; Veeraraghavalu, K.; Tergaonkar, V.; Liu, Y.; Androphy, E.J.; Stanley, M.A.; Krishna, S. Human Papillomavirus Type 16 E6 Amino Acid 83 Variants Enhance E6-Mediated MAPK Signaling and Differentially Regulate Tumorigenesis by Notch Signaling and Oncogenic Ras. J. Virol. 2004, 78, 5934-5945. [CrossRef] [PubMed]

145. Sichero, L.; Sobrinho, J.S.; Villa, L.L. Oncogenic potential diverge among human papillomavirus type 16 natural variants. Virology 2012, 432, 127-132. [CrossRef]

146. Chen, J.; Che, L.; Xu, C.; Zhao, S.; Yang, J.; Li, M.; Li, G.; Shen, Y. Cardio-facio-cutaneous syndrome-associated pathogenic MAP2K1 variants activate autophagy. Gene 2020, 733, 144369. [CrossRef] [PubMed]

147. White, E.; Mehnert, J.M.; Chan, C.S. Autophagy, Metabolism, and Cancer. Clin. Cancer Res. 2015, 21, 5037-5046. [CrossRef]

148. Poillet-Perez, L.; White, E. Role of tumor and host autophagy in cancer metabolism. Genes Dev. 2019, 33, 610-619. [CrossRef]

149. Hochmann, J.; Sobrinho, J.S.; Villa, L.L.; Sichero, L. The Asian-American variant of human papillomavirus type 16 exhibits higher activation of MAPK and PI3K/AKT signaling pathways, transformation, migration and invasion of primary human keratinocytes. Virology 2016, 492, 145-154. [CrossRef] [PubMed]

150. Sozen, B.; Ozturk, S.; Yaba, A.; Demir, N. The p38 MAPK signalling pathway is required for glucose metabolism, lineage specification and embryo survival during mouse preimplantation development. Mech. Dev. 2015, 138, 375-398. [CrossRef] 
151. McFalls, E.O.; Hou, M.X.; Bache, R.J.; Best, A.; Marx, D.; Sikora, J.; Ward, H.B. Activation of p38 MAPK and increased glucose transport in chronic hibernating swine myocardium. Am. J. Physiol. Hear. Circ. Physiol. 2004, 287, 1328-1334. [CrossRef]

152. Ma, D.; Li, Y.; Xiao, W.; Peng, L.; Wang, L.; Liao, Z.; Hu, L. Achyranthes bidentata extract protects chondrocytes functions through suppressing glycolysis and apoptosis via MAPK/AKT signaling axis. Am. J. Transl. Res. 2020, 12, 142-152.

153. Wang, C.W.; Purkayastha, A.; Jones, K.T.; Thaker, S.K.; Banerjee, U. In vivo genetic dissection of tumor growth and the Warburg effect. eLife 2016, 5, e18126. [CrossRef]

154. Lee, S.Y.; Jeon, H.M.; Ju, M.K.; Kim, C.H.; Yoon, G.; Han, S.I.; Park, H.G.; Kang, H.S. Wnt/snail signaling regulates cytochrome c oxidase and glucose metabolism. Cancer Res. 2012, 72, 3607-3617. [CrossRef]

155. Bahrami, A.; Hasanzadeh, M.; ShahidSales, S.; Yousefi, Z.; Kadkhodayan, S.; Farazestanian, M.; Joudi Mashhad, M.; Gharib, M.; Mahdi Hassanian, S.; Avan, A. Clinical Significance and Prognosis Value of Wnt Signaling Pathway in Cervical Cancer. J. Cell. Biochem. 2017, 118, 3028-3033. [CrossRef] [PubMed]

156. Subramaniam, S.; Jeet, V.; Clements, J.A.; Gunter, J.H.; Batra, J. Emergence of microRNAs as key players in cancer cell metabolism. Clin. Chem. 2019, 65, 1090-1101. [CrossRef]

157. Lajer, C.B.; Garnæs, E.; Friis-Hansen, L.; Norrild, B.; Therkildsen, M.H.; Glud, M.; Rossing, M.; Lajer, H.; Svane, D.; Skotte, L.; et al. The role of miRNAs in human papilloma virus (HPV)-associated cancers: Bridging between HPV-related head and neck cancer and cervical cancer. Br. J. Cancer 2012, 106, 1526-1534. [CrossRef] [PubMed]

158. Chopjitt, P.; Pientong, C.; Bumrungthai, S.; Kongyingyoes, B.; Ekalaksananan, T. Activities of E6 protein of human papillomavirus 16 Asian variant on miR-21 up-regulation and expression of human immune response genes. Asian Pac. J. Cancer Prev. 2015, 16, 3961-3968. [CrossRef] [PubMed]

159. Ni, K.; Wang, D.; Xu, H.; Mei, F.; Wu, C.; Liu, Z.; Zhou, B. miR-21 promotes non-small cell lung cancer cells growth by regulating fatty acid metabolism. Cancer Cell Int. 2019, 19, 219. [CrossRef]

160. Lopaschuk, G.D.; Ussher, J.R.; Folmes, C.D.L.; Jaswal, J.S.; Stanley, W.C. Myocardial fatty acid metabolism in health and disease. Physiol. Rev. 2010, 90, 207-258. [CrossRef]

161. Salazar-Roa, M.; Malumbres, M. Fueling the Cell Division Cycle. Trends Cell Biol. 2016, 27, 69-81. [CrossRef] [PubMed]

162. Ji, K.; Mayernik, L.; Moin, K.; Sloane, B.F. Acidosis and proteolysis in the tumor microenvironment. Cancer Metastasis Rev. 2019, 38, 103-112. [CrossRef]

163. Niccoli, S.; Abraham, S.; Richard, C.; Zehbe, I. The Asian-American E6 Variant Protein of Human Papillomavirus 16 Alone Is Sufficient To Promote Immortalization, Transformation, and Migration of Primary Human Foreskin Keratinocytes. J. Virol. 2012, 86, 12384-12396. [CrossRef]

164. Becker, H.M.; Klier, M.; Deitmer, J.W. Carbonic Anhydrase: Mechanism, Regulation, Links to Disease, and Industrial Applications. Subcell. Biochem. 2014, 75, 105-134. [CrossRef]

165. Kirkpatrick, J.P.; Rabbani, Z.N.; Bentley, R.C.; Hardee, M.E.; Karol, S.; Meyer, J.; Oosterwijk, E.; Havrilesky, L.; Secord, A.A.; Vujaskovic, Z.; et al. Elevated CAIX expression is associated with an increased risk of distant failure in early-stage cervical cancer. Biomark. Insights 2008, 2008, 45-55. [CrossRef]

166. Nguyen, H.P.; Yi, D.; Lin, F.; Viscarra, J.A.; Tabuchi, C.; Ngo, K.; Shin, G.; Lee, A.Y.; Wang, Y.; Sul, H.S. Aifm2, a NADH Oxidase, Supports Robust Glycolysis and Is Required for Cold- and Diet-Induced Thermogenesis. Mol. Cell 2020, 77, 600-617.e4. [CrossRef]

167. Marshall, K.R.; Gong, M.; Wodke, L.; Lamb, J.H.; Jones, D.J.L.; Farmer, P.B.; Scrutton, N.S.; Munro, A.W. The human apoptosisinducing protein AMID is an oxidoreductase with a modified flavin cofactor and DNA binding activity. J. Biol. Chem. 2005, 280, 30735-30740. [CrossRef] [PubMed]

168. Chopjitt, P.; Pientong, C.; Sunthamala, N.; Kongyingyoes, B.; Haonon, O.; Boonmars, T.; Kikawa, S.; Nakahara, T.; Kiyono, T.; Ekalaksananan, T. E6D25E, HPV16 Asian variant shows specific proteomic pattern correlating in cells transformation and suppressive innate immune response. Biochem. Biophys. Res. Commun. 2016, 478, 417-423. [CrossRef]

169. Chatterjee, A.; Gupta, S. The multifaceted role of glutathione S-transferases in cancer. Cancer Lett. 2018, 433, 33-42. [CrossRef] [PubMed]

170. Lace, M.J.; Anson, J.R.; Klussmann, J.P.; Wang, D.H.; Smith, E.M.; Haugen, T.H.; Turek, L.P. Human Papillomavirus Type 16 (HPV-16) Genomes Integrated in Head and Neck Cancers and in HPV-16-Immortalized Human Keratinocyte Clones Express Chimeric Virus-Cell mRNAs Similar to Those Found in Cervical Cancers. J. Virol. 2011, 85, 1645-1654. [CrossRef] [PubMed]

171. Jackson, R.; Rosa, B.A.; Lameiras, S.; Cuninghame, S.; Bernard, J.; Floriano, W.B.; Lambert, P.F.; Nicolas, A.; Zehbe, I. Functional variants of human papillomavirus type 16 demonstrate host genome integration and transcriptional alterations corresponding to their unique cancer epidemiology. BMC Genom. 2016, 17, 851. [CrossRef]

172. Alper, S.L.; Sharma, A.K. The SLC26 gene family of anion transporters and channels. Mol. Asp. Med. 2013, 34, 494-515. [CrossRef]

173. Çalişkan, M. The metabolism of oxalic acid. Turk. J. Zool. 2000, 24, 103-106.

174. Baker, P.R.S.; Cramer, S.D.; Kennedy, M.; Assimos, D.G.; Holmes, R.P. Glycolate and glyoxylate metabolism in HepG2 cells. Am. J. Physiol. Cell Physiol. 2004, 287, 1359-1366. [CrossRef] [PubMed]

175. Sun, X.Y.; Gan, Q.Z.; Ouyang, J.M. Calcium oxalate toxicity in renal epithelial cells: The mediation of crystal size on cell death mode. Cell Death Discov. 2015, 1, 1-8. [CrossRef]

176. Scimeca, M.; Giannini, E.; Antonacci, C.; Pistolese, C.A.; Spagnoli, L.G.; Bonanno, E. Microcalcifications in breast cancer: An active phenomenon mediated by epithelial cells with mesenchymal characteristics. BMC Cancer 2014, 14, 286. [CrossRef] [PubMed] 
177. Castellaro, A.M.; Tonda, A.; Cejas, H.H.; Ferreyra, H.; Caputto, B.L.; Pucci, O.A.; Gil, G.A. Oxalate induces breast cancer. BMC Cancer 2015, 15, 761. [CrossRef] [PubMed]

178. Patel, M.; Yarlagadda, V.; Adedoyin, O.; Saini, V.; Assimos, D.G.; Holmes, R.P.; Mitchell, T. Oxalate induces mitochondrial dysfunction and disrupts redox homeostasis in a human monocyte derived cell line. Redox Biol. 2018, 15, 207-215. [CrossRef]

179. Chaiyarit, S.; Thongboonkerd, V. Changes in mitochondrial proteome of renal tubular cells induced by calcium oxalate monohydrate crystal adhesion and internalization are related to mitochondrial dysfunction. J. Proteome Res. 2012, 11, 3269-3280. [CrossRef] 